\title{
Enplegu banaketaren esperientzia krisian: Gipuzkoako kasua, gizarte ekonomia azpimarratuz
}

\author{
The experience of job distribution during the recession: \\ the case of Gipuzkoa, redefining the social economy
}

Aitziber Mugarra-Elorriaga (zuz.)

\author{
Arantza ECHANIZ-BARRONDO \\ Marta ENCISO-SANTOCILDES \\ Mariola Serrano-Argüeso \\ Laura GómEZ-URQUiJo \\ Elena Blanco-Meruelo \\ Nerea Ereñaga-DeJesús
}

Gizarte Garapena, Ekonomia eta Berrikuntza Pertsonentzat (EDISPe)

Deustuko Unibertsitatea

aitziber.mugarra@deusto.es

DOI: $10.1387 /$ reves.20512

Fecha de entrada: 01/06/2018

Fecha de aceptación: 25/07/2018

Aurkibidea: I. Sarrera.-II. Enplegu banaketarako neurrien mapa. 1. Baimenak. 2. Lanaldia malgutzeko neurriak. 3. Erretiroko neurriak. 4. Neurri orokorrak.-III. landa-lana: Gipuzkoako erakundeetan 2008tik 2015tara enplegua banatzeko hartutako neurriak. 0. Orokorrean. 0.1 . Langileen banaketa generoaren arabera. 0.2. Enplegua banatzeko neurrien bilakaera. 0.3. Enplegu banatzeko neurriek eragindako kolektiboak. 0.4. Kontratazio berriak. 1. Lan denboraren kudeaketa. 1.1. Lanaldia. 1.2. Asteko lanorduak. 1.3. Lan denboraren murrizketak. 1.4. Enpresaren eta langileen eta haien ordezkarien arteko akordioak. 1.5. Aparteko lanorduak. 1.6. Lanaldi trinkotua. 2. Baimenak. 2.1. Lanaldiaren aldi baterako murrizketak. 2.2. Eszendentziak. 2.3. Prestakuntzarako baimenak edo baimen partzialki ordainduak. 3. Enplegua banatzeko neurriak erakundearen arrazoiak direla eta. 3.1. Enplegua erregulatzeko espedienteak. 3.2. Pertsonak beste lantoki batzuetara mugitzea. 4. Erretiroak. 4.1. Erretiro partzialak eta txandako lan kontratuak. 4.2. Erretiro aurreratuak.-IV. Emaitzen sintesia gizarte ekonomiaren ikuspuntutik.-V. Bibliografia. 


\title{
Laburpena
}

Krisian lan egiteko aukeren banaketa desorekatua denez, enplegua banatzeko neurriak planteatzen dira lan egiteko benetako aukerak modu orekatuan birbanatzeko lanpostu eske dabiltzan pertsona guztien artean. Horrek berekin dakar: Ian denbora berrantolatzea, lana beste era batera banatzeko; lan denbora berri horretara langile gehiago egokitzea; enpleguaren eta soldaten kalitatea bermatzea; eta langileen bizi kalitatea eta ongizatea babestea. Egungo egoeran, bi neurri mota ezagutzen ditugu lanaren banaketan laguntzen dutenak: Alde batetik, banaketa huts-hutseko neurriak, enplegua sortzen dutenak. Eta beste aldetik dagoen enplegua mantentzeko balio duten banaketa neurriak, eta guzti horiek lau sail nagusitan sailkatuta agertzen dira guk diseinatutako Enplegu banatzeko neurrien mapan. Artikulu honetan azaltzen ditugu zeintzuk dira neurri horiek eta nola aplikatu dira 2008tik 2014raino Gipuzkoako erakundeetan, azpimarratzen gizarte ekonomiaren kasua eta generoaren ikuspuntua.

\section{Hitz gakoak:}

Enplegu-banaketa, gizarte ekonomia, generoaren ikuspuntua, enplegu sortzea, enplegu mantentzea.

\begin{abstract}
We are currently faced with an unequal distribution of employment opportunities, which has led to a rethinking of the Employment Sharing measures, as a means of reallocating in a balanced way job opportunities really available to all jobseekers. This involves: rearranging working time, leading to a new work distribution; adapting a greater number of working people to this new time of work; ensuring quality of employment and wages; and protecting quality of life and well-being of working people. Nowadays we recognize two types of measures that contribute to distribution of employment: On the one hand, measures of pure distribution, creating new employment; on the other, distribution measures in order to maintain existing employment. All of them classified into four main sections on the Map of Measures for the Distribution of Employment we have designed. In this article we present what these measures are and how they have been applied in organizations in Gipuzkoa from 2008 to 2014, highlighting the case of the social economy and the gender point of view.
\end{abstract}

\section{Keywords:}

Employment sharing, social economy, gender perspective, employment maintenance, employment creation.

\section{Claves Econlit:}

A110, P510.

B55, J54, J01, J16, J26, J29. 


\section{Sarrera}

Krisian lan egiteko aukeren banaketa desorekatua denez, enplegua banatzeko neurriak planteatzen dira lan egiteko benetako aukerak modu orekatuan birbanatzeko lanpostu eske dabiltzan pertsona guztien artean. Horrek berekin dakar: 1) Lan denbora berrantolatzea, lana beste era batera banatzeko; 2) Lan denbora berri horretara langile gehiago egokitzea; 3) Enpleguaren eta soldaten kalitatea bermatzea; 4) Langileen bizi kalitatea eta ongizatea babestea.

Egia esan, lan banaketaren eztabaida ez da berria: 70. hamarkadatik hona asko idatzi da horri buruz. Honen bilakaera grafikoki erakusteko GoogleScholarren erreferentziak hartuko ditugu iturri: argi erakusten du 90.tik aurrera erreferentziak areagotzen direla.

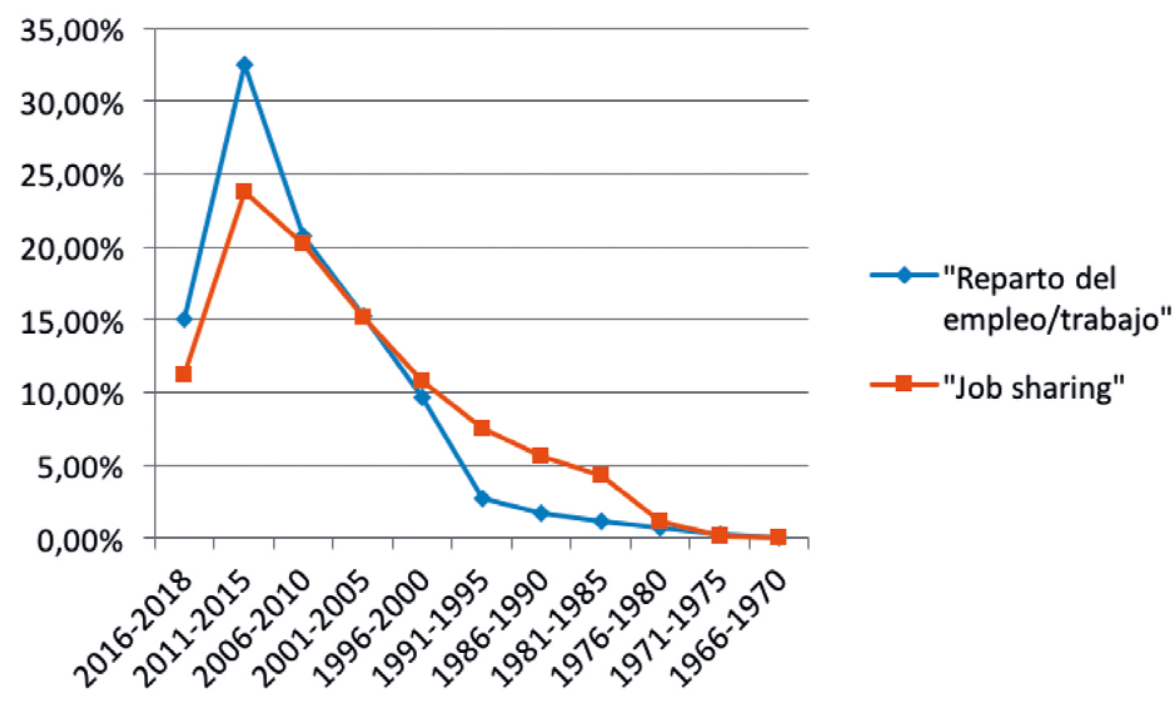

Iturria: nik egindakoa.

Eta krisialdiak modan jarritako gaia dela ikus dezakegu Web of Knowledgen zita sistema aztertuta: 80 erreferentzia daude «job sharing» gaiari buruz eta 2007-2008tik aurrera argi eta garbi haziz doaz. 


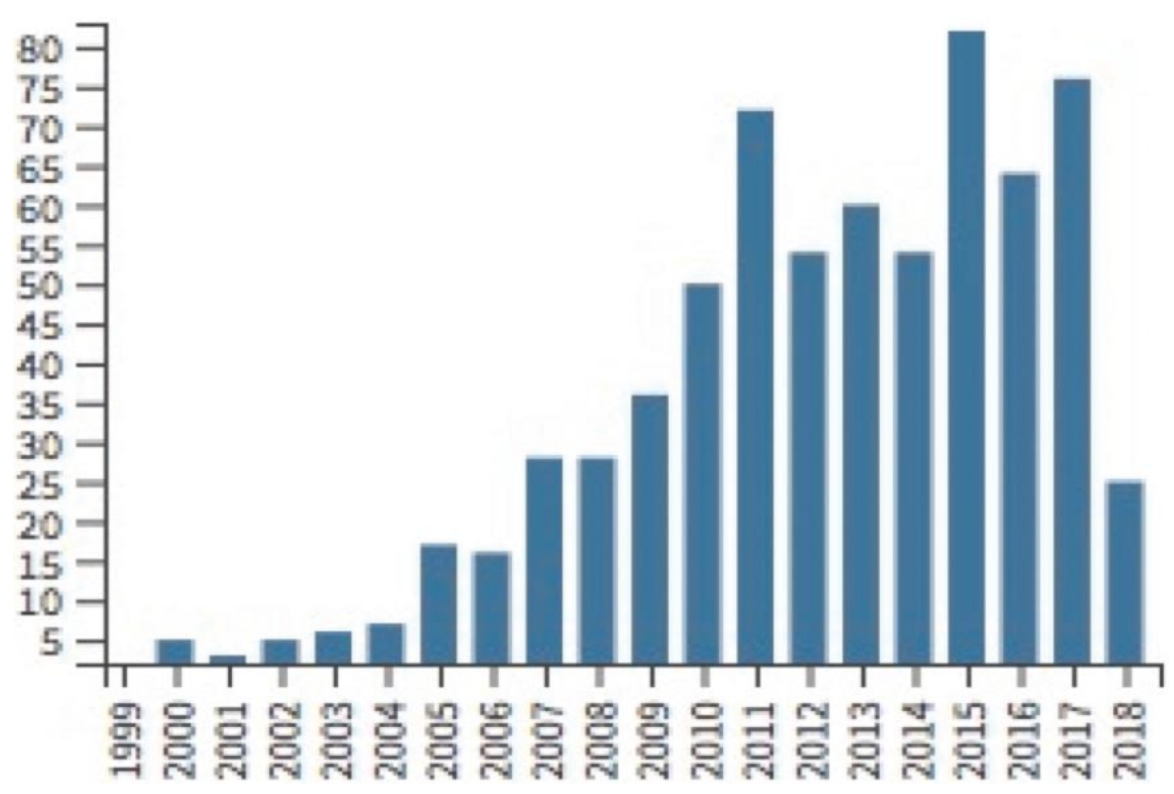

Iturria: Web of Knowledge.

Gure esparru geografikoan aipatzekoa da Ekonomiaz aldizkariak publikatutako monografikoa 1996an. Bertan ikus daiteke momentu hartan Euskadin sortutako eztabaida publikoa eta gizarte eragile bakoitzaren ikuspuntua. Adibide modura, garai horretako beste iturri batzuk dira AZNAR (1994), RIFKIN (1995), ALONSO \& PEREZ (1996), ANISI (1996), BILBAO (1996), MORRISSEY et al (1996), RODRIGUEZ (1996), LEHNDORF \& BOSCH (1997), DE LA PUERTA (1998), JAUREGUI et al (1998), FINA \& PEREZ (1999), MEDINA (1999), ROSELL \& TRIGO (2000).

Azkenengo krisiak enplegu banaketari buruzko interesa berriro bizitu du eta Euskadin Lan Harremanak aldizkariak 2016an argitatutako zenbaki monografiko aipatu behar dugu. Honekin batera aurkitu ditzakegu beste argitalpen batzuk: BOSCH (2010), GRAAF (2010), NEF (2010), RAFOLS (2010), RECIO (2012), CASTRILLON (2017), 21 Proiektua (2017), FERRER (2018), adibidez.

Denboraren logikak ere aldatzen ari dira: alde batetik, denbora ekonomikoa, produktiboa, emankorra, lanarekin guztiz konektatua, eta beste 'denbora': aisialdia, familirako denbora. Keynesek aipatzen zuen jada 1930ean, eta besteok ere geroago (AZNAR, 1994; JAUREGUI et al., 1998...). Aznarrek aukeraketa bat planteatzen du: «sociedad bipolar que es 
exactamente lo opuesto a la sociedad dual: la participación de cada hombre (sic) en dos esferas complementarias y opuestas, no la ruptura entre dos categorías de hombres» (AZNAR, 1994, 320 or.): landunak eta langabeak, hau da, denborako behartsuak vs diruko behartsuak (21 Proiektua, 88 or). Horrela ulertu behar dira "Trabajar menos para trabajar todos» bezalako tituluak eta proposamenak.

Gizon eta emakueen arteko lan banaketa gaia protagonista da erreferentzi askotan ere: berriro denborarekin konektatuta, kasu honetan denbora 'produktiboa' eta denbora 'erreproduktiboa' erlazionatuz (RECIO, 2012, 76 or; RODRIGUEZ, 1996...).

Beste batzuetan giroaren defentzaren helburua da lan banaketaren proposamen azpian agertzen den gakoa. Adibidez, GRAAF proposatzen du denbora ondareen ordez trukatzea etorkizun iraunkorra lortzeko: «canjeando las mejoras de productividad por tiempo, reduciendo las horas de trabajo y compartiéndolas de manera equitativa». (GRAAF, 2010, 331 or.) Bakarrik horrela lortuko da gizartearen inpaktua ingurumenean gutxitzea (RAFOLS, 2010, 1 or; NEF, 2010; RECIO, 2012, 73 or).

Azken finean, lan-garaiaren gainean eztabaidatzea gure gizarte eredu gainean eztabaidatzea da (RECIO, 2012, 77 or). Gaur egun eztabaida horretan oinarrizko errenta, lan-garaiaren murriztapena eta bermatuko enplegua kontzeptuak ere agertzen dira (21 Proiektua, 2017, 85 or. eta hur).

Epe luze honetan proposamen asko egin dira, baita ere esperimentu ezberdinak munduan zehar. Esperimentu horiek aztertu dira eta EgiaCareaga Fundazioan dagoen Ikerketa Zentrua 2015ean «lanorduak gutxitzeko neurri batzuen eraginkortasunaren inguruan dagoen ebidentzia enpirikoa» laburbildu ditu. Bereziki, Alemanian eta Frantzian egindako esperientzien gainean. «Lanorduen murrizketaren neurri desberdinen eraginkortasunaren inguruan argitaratutako azterlan zientifikoen berrikusketa» egin du, eta emaitzak argiratatuta daude jadanik (SIIS, 2015; SIIS, 2016).

Oso esanguratzua agertzen zaigu Espainako Kontseilu Ekonomiko eta Sozialaren (CESE, 2018) azkenengo txostena lanaren etorkizunari buruz: txosten osoan ez da behin aipatzen lan banaketa. Kezkak enpleguaren ordezkapena, sorrera eta transformazioarekin konektatua daude gehien bat, teknologiaren aurrerapen ondorioz. Antzekoa gertatzen da Eskubide Sozialeko Europako zutabearekin: 20 printzipiotan sailkatuta, lehenengo hamarrak lanarekin konektatuta daude baina 'lan banaketa' ez da espresuki aipatzen, eta 9. printzipioan bakarrik agertzen dira konexio inplizituak bizitza profesionalaren eta bizitza pribatuaren arteko oreka lantzen duenean.

Giro honetan eta Gipuzkoako Foru Aldundiak eskatuta, krisi barruan 7 urte egon ondoren, momentu aproposa zirudien enplegu banaketarako dauden neurriak eta nola erabili diren enpresetan aztertzeko, bereziki gi- 
zarte ekonomia sektorean ${ }^{1}$. Eztabaida teorikoak alde batean utziz, gure lehenengo erronka neurri horien katalogoa identifikatzea izan da, eta emaitza «Enplegu banatzeko neurrien mapan» daukagu. Bigarren pausoa erabileraren datuak aurkitzea izan da eta horretarako Gipuzkoan landa-lana egin dugu: hemen aurkeztutako emaitzak Gipuzkoako erakundeen artean zorizko lagin bati telefonoz egindako galde-sorta baten ondorio dira, galde-sortaren eremu desberdinen erantzulea giza baliabideen arduraduna edo kudeatzailea izan delarik.

\section{Enplegu banaketarako neurrien mapa}

Egungo egoeran, bi neurri mota ezagutzen ditugu lanaren banaketan laguntzen dutenak: Alde batetik, banaketa huts-hutseko neurriak, enplegua sortzen dutenak. Eta beste aldetik dagoen enplegua mantentzeko balio duten banaketa neurriak.

Eta neurri horiek lau sail nagusitan sailkatzen ditugu:

\section{Baimenak}

Ordaindu gabeko baimenak: Langileak honenbeste egun, aste, hilabete edo urte libre hartzeko aukera izatea bere gauzetarako. Lan egin gabeko egun batzuk hartzeko eskubidea, ordainsari ekonomikorik gabe. Mota honetako baimenak dira nahitaezko eszedentziak, borondatezkoak eta seme-alabak edo senideak zaintzekoak.

Ordaindutako baimenak: Langileak honenbeste ordu, egun edo aste libre hartzeko aukera izatea lan araudian aitortuta dauden norberaren gauzetarako (heriotza, jaiotza, adopzioa, harrera, ospitaleratzea, ezkontza...), eta hitzarmen kolektiboetan ezarrita dauden norberaren gauzetarako.

Prestakuntzako baimenak eta aldi baterako kontratazio berria: Langileak eskubidea du lanbideko prestakuntzarako edo hobekuntzarako baimenak eman dakizkion, lanpostua gordeta baina ordainsaririk jaso gabe.

Prestakuntzako baimen partzialki ordainduak eta aldi baterako kontratazio berria: Langileak honenbeste ordu, egun edo aste libreko aldi bat hartzeko aukera, ohiko soldataren \% honenbeste jasoz.

${ }^{1}$ Horregatik, Gipuzkoako Foru Aldundiko Berrikuntzako, Landa Garapeneko eta Turismoko Departamentuak finantzatu du ikerketa berezia 2015ean, eta hona hemen aurkitutako informazio interesgarri batzuk. 


\section{Lanaldia aldi baterako murriztea eta ordezko kontratazioa:}

- Bularra emateko, haurrak 9 hilabete izan arte.

- Seme-alabek, denbora baino lehen jaio direlako edo dena delakoagatik, erditu ondoren ospitalean geratu beharra dutenean.

- Hamabi urte baino gutxiagoko haur bat edo desgaitasun fisiko, psikiko edo sentsoriala duen eta ordaindutako jarduerarik egiten ez duen pertsona bat zuzenean zaintzeko.

- Bere kabuz baliatu ezin den eta ordaindutako jarduerarik egiten ez duen senide bat zuzenean zaintzeko, odol-ahaidetasun edo ezkontza-ahaidetasunezko bigarren mailaraino (adineko pertsonak zaintzeko).

\section{Lanaldia malgutzeko neurriak}

Orduen poltsa sortzea: Langileen lanaldiaren zati bat enpresaren antolaketa eta ekoizpen beharretara egokitzeko mekanismoa. Urtean zehar lan egindako orduak eta lan egin gabekoak zenbatzen dira, langile bakoitzaren orduen saldo positiboak edo negatiboak sortuz.

Lan asteak trinkotzea: Lanaldi arruntari dagozkion lanorduak egun gutxiagotan eta jardunaldi luzeagoetan egitea.

Aparteko orduak kentzea eta beste pertsona bat lanaldi partzialean kontratatzea: Ohiko gehienezko lanalditik gorako lanordurik ez egitea, langabezian dauden pertsonei kontratu partzialak egiteko.

Lanaldi atipikoak: Txandaka, gauez eta asteburuetan lan egitea. Lana ordutegi edo lanegun horien arabera antolatzen da.

\section{Erretiroko neurriak}

Erretiro partziala eta txandako lan kontratua: Lanaldi partzialeko kontratua erretiro aurreratuagatik, hau da, lanaldia \%25-30 murriztea, soldata hein berean murriztuta eta erretiro partzialeko pentsioa gehituta. Neurri horri txandako lan kontratu bat gehitzen zaio; hau da, beste pertsona bat sartzen da enpresan, erretiro partziala hartu duen pertsonak utzi duen lanaldia betetzeko.

Erretiro aurreratua eta lanaldi partzialeko kontratu berria: Langileak denbora baino lehen hartzen du erretiroa, enpresarekin negoziatuta. Enpresa arduratuko da neurri hori ekonomikoki konpentsatzeaz/osatzeaz. Neurri horri lanaldi partzialeko kontratazio bat gehitzen zaio. 
4. Neurri orokorrak

Lanaldi partzialeko kontratazioa: Egunean, astean, hilean edo urtean honenbeste ordutako zerbitzuak emateko adosten den kontratua. Ordu kopurua lanaldi osoko langile batena baino txikiagoa da. Mugarik gabe edo iraupen jakin baterako egin daiteke.

Langileak beste lantoki edo erakundeetara mugitzea: Enpresaren alde bakarreko erabakia edo aldeen artean adostua, langileak zerbitzuak ematen dituen tokia aldatzeko, antolaketa arrazoiak direla medio, horrela plantillaren enplegua mantentzeko. Lekualdaketa aldi baterakoa da eta lantokia probintzia bereko beste herri batera aldatzea dakar, langileari bizilekua aldarazi gabe.

\section{1. grafikoa}

Enplegua banatzeko neurrien bilakaera

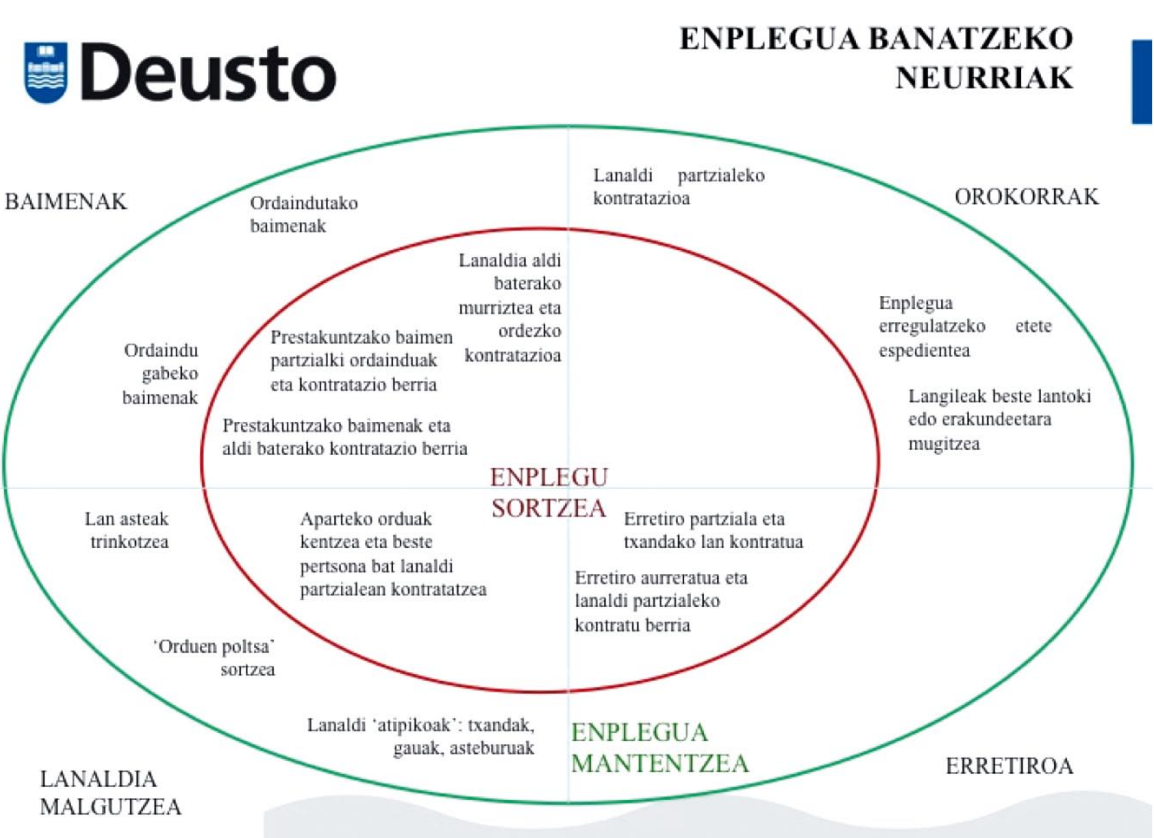

Iturria: geuk sortua.

Enplegua erregulatzeko etete espedientea: Langile guztien edo batzuen kontratuak aldi baterako etetea. Kontratua etenda geratzen den den- 
boran, langileek langabeziako prestazioa jasotzen dute. Lanaldia \%10-70 bitartean murriztu daiteke aldi baterako, eguneko, asteko, hileko edo urteko lanalditik kalkulatuta. Epe horretan ezin da aparteko ordurik egin, ezinbesteko kasuan ez bada. Lanaldi errealaren eta murriztuaren arteko aldeari dagokion langabeziako prestazioa jasotzen da.

\section{Landa-lana: Gipuzkoako erakundeetan 2008tik 2015tara enplegua banatzeko hartutako neurriak}

\section{Orokorrean}

\subsection{LANGILEEN BANAKETA GENEROAREN ARABERA}

Ikerketan parte hartu duten enpresetako hiru langiletik ia bi $(\% 64,9)$ gizonezkoak dira eta \%35,1 emakumezkoak. Banaketa hori berdina da tamaina guztietako enpresetan, erantzukizun mugatuko sozietateetan nahiz gizarte ekonomiakoetan. Gizonezkoen nagusigoa are handiagoa da sozietate anonimoetan. Beste forma juridiko bateko erakundeetan, berriz, emakumeen kopurua handiagoa da.

\section{1. taula}

Langileak generoaren arabera forma juridikoa bereizita (\%)

G.19. Zein da zure erakundean dagoen emakume eta gizonen portzentajea?

\begin{tabular}{l|cccc}
\hline \multirow{2}{*}{ Kategoria } & \multicolumn{4}{|c}{ Forma juridikoa } \\
\cline { 2 - 5 } & $\begin{array}{c}\text { Elkarte } \\
\text { mugatua }\end{array}$ & $\begin{array}{c}\text { Akziokako } \\
\text { elkartea }\end{array}$ & $\begin{array}{c}\text { Gizarte } \\
\text { ekonomia }\end{array}$ & $\begin{array}{c}\text { Bestelako } \\
\text { elkartea }\end{array}$ \\
\hline Emakumeak & 33,1 & 26,8 & 37,5 & 61,4 \\
Gizonak & 66,9 & 73,2 & 62,5 & 38,6 \\
\hline
\end{tabular}

Iturria: geuk sortua.

\subsection{ENPLEGUA BANATZEKO NEURRIEN BILAKAERA}

Ikerketa honen beste adierazle garrantzitsu bat izan da jakitea krisi ekonomikoan zenbateraino aplikatu diren enplegua banatzeko dauden neurri desberdinak ikerketan parte hartu duten erakundeetan.

Ikusi denez, erakunde gehienetan, hots, \%87tan, halako neurriak mantendu egin dira. Bakarrik erakundeen \%10,5ek halako neurri gehiago hartu 
dutela diote; \%2,5ek, ordea, neurriak gutxitu dituztela. Banaketa hori, gainera, nahiko egonkorra da nortasun juridiko guztietako erakundeetan.

\section{2. taula}

Enplegua banatzeko neurrien bilakaera forma juridikoa bereizita (\%)

G.17. Krisiaren eraginez, lan-banaketarekin lotutako neurriak, esate baterako, lanaldi partzialeko kontratazioak, lanaldiaren murrizketak, ordutegi aldetiko malgutasunak, etab...

\begin{tabular}{l|cccc}
\hline \multirow{2}{*}{\multicolumn{1}{c|}{ Kategoria }} & \multicolumn{4}{|c}{ Forma juridikoa } \\
\cline { 2 - 5 } & $\begin{array}{c}\text { Elkarte } \\
\text { mugatua }\end{array}$ & $\begin{array}{c}\text { Akziokako } \\
\text { elkartea }\end{array}$ & $\begin{array}{c}\text { Gizarte } \\
\text { ekonomia }\end{array}$ & $\begin{array}{c}\text { Bestelako } \\
\text { elkartea }\end{array}$ \\
\hline Areagotu egin dira & 12,1 & 7,6 & 11,8 & 11,5 \\
Berdin mantentzen dira & 85,7 & 89,4 & 88,2 & 84,6 \\
Gutxitu egin dira & 2,2 & 3,0 & 0,0 & 3,8 \\
\hline
\end{tabular}

Iturria: geuk sortua.

\subsection{ENPLEGU BANATZEKO NEURRIEK ERAGINDAKO KOLEKTIBOAK}

Egindako galde-sortarekin, krisi ekonomikoan Gipuzkoako erakundeetan enplegua banatzeko hartutako neurriak ezagutzeaz gain, neurri horiek kolektibo guztiei berdin eragin dieten ala kolektibo zehatz batzuetara bideratu diren ere jakin nahi izan dugu.

Horretarako, hiru kolektibo bereizi ditugu: gazteak, emakumeak eta erretirotik hurbil dauden pertsonak. Erakundeei eskatu zaie zehazteko enplegua banatzeko neurri bakoitza zein portzentajetan erabili den hiru kolektibo horietako bakoitzean. Gazte guztietatik \%30engan izan dute eragina halako neurriek. Emakumeen kasuan, \%27rengan izan dute eragina. Erretiroa hartzeko adinetik hurbil daudenengan, berriz, eragina txikiagoa da \%19,8 baitira neurriek ukitu dituztenak.

Emaitzak ikusita badirudi enplegua banatzeko neurriek eragin txikiagoa izan dutela hiru kolektiboetan gizarte ekonomiako erakundeetan. 


\section{3. taula}

Enplegua banatzeko neurriek eragindako kolektiboak forma juridikoa bereizita $(\%)$

G.16. Zure erakundeko pertsonen perfilari dagokionez

\begin{tabular}{l|cccc}
\hline \multirow{2}{*}{ Kategoria } & \multicolumn{4}{|c}{ Forma juridikoa } \\
\cline { 2 - 5 } & $\begin{array}{c}\text { Elkarte } \\
\text { mugatua }\end{array}$ & $\begin{array}{c}\text { Akziokako } \\
\text { elkartea }\end{array}$ & $\begin{array}{c}\text { Gizarte } \\
\text { ekonomia }\end{array}$ & $\begin{array}{c}\text { Bestelako } \\
\text { elkartea }\end{array}$ \\
\hline $\begin{array}{l}\text { Erakundeko persona gazteetatik, } \\
\text { lan-banaketari buruzko neurriak } \\
\text { jasan dituzten pertsona gazteen ba- } \\
\text { tez besteko portzentaia }\end{array}$ & 33,5 & 34,3 & 4,1 & 21,9 \\
\hline $\begin{array}{l}\text { Erakundean erretiroa hartzeko } \\
\text { adinetik hurbil dauden pertsonen } \\
\text { artetik, lan-banaketari buruzko } \\
\text { neurriak jasan dituzten erretiroa }\end{array}$ & 16,2 & 30,4 & 11,0 & 11,2 \\
$\begin{array}{l}\text { hartzeko adinetik hurbil dauden } \\
\text { pertsonen batez besteko portzen- } \\
\text { taia }\end{array}$ & & & & \\
\hline $\begin{array}{l}\text { Erakundeko emakumeen artetik } \\
\text { lan-banaketari buruzko neurriak } \\
\text { jasan dituzten emakumeen batez } \\
\text { besteko portzentaia }\end{array}$ & 26,4 & 33,1 & 11,8 & 22,1 \\
\hline
\end{tabular}

Iturria: geuk sortua.

\subsection{Kontratazio Berriak}

Eusko Jaurlaritzaren datuen arabera, krisi ekonomikoaren ondorioz, Euskadiko kontratazioak ordura arteko goranzko joera alderantzikatu zuen. Urtetik urterako jaitsierarik handiena 2009an gertatu zen, $-\% 18,1$ hain zuzen ere. Jardueraren hazkunde motelarekin bat, 2010ean eta $2011 \mathrm{n}$ kontratuek gora egin zuten oso poliki, baina gero berriz jaitsi ziren jarduera uzkurtu zenean. Izan ere, Euskadiko barne produktu gordina \%2 jaitsi zen 2012an eta \%1,7 2013an. 2014an, aldiz, Euskadiko BPGd-ak gora egin zuen eta horrek enplegu sorkuntza ekarri zuen: kontratazioa aurreko urtekoa baino \%12,1 handiagoa izan zen².

2 Dirección de Economía y Planificación. Gobierno Vasco. Informe Anual de la economía vasca. 2014. Vitoria: Departamento de Hacienda y Finanzas. 2015. 
Baina gure landa-lanari erreparatzen badiogu, krisia hasi zenetik Gipuzkoako erakundeen \%86k egin dituzte kontratu berriak. Eta galde-sortako 9. galderaren erantzunei erreparatuta: «2008. urteaz geroztik, zure erakundean kontratazio berririk egin al da?», ematen du sozietate anonimoek eta gizarte ekonomiakoek kontratazio maila goragokoak dituztela lagin osoak baino.

\section{4. taula}

Kontratazio berriak forma juridikoa bereizita (\%)

G.9. 2008. urteaz geroztik, zure erakundean kontratazio berririk egin al da? Bai

\begin{tabular}{cccc}
\hline \multicolumn{4}{c}{ Forma juridikoa } \\
\hline Elkarte mugatua & Akziokako elkartea & Gizarte ekonomia & Bestelako elkartea \\
\hline 79,1 & 93,9 & 94,1 & 84,6 \\
\hline
\end{tabular}

Iturria: geuk sortua.

\section{2. grafikoa}

Azken urteetan kontratutako pertsonak generoaren arabera (\%)

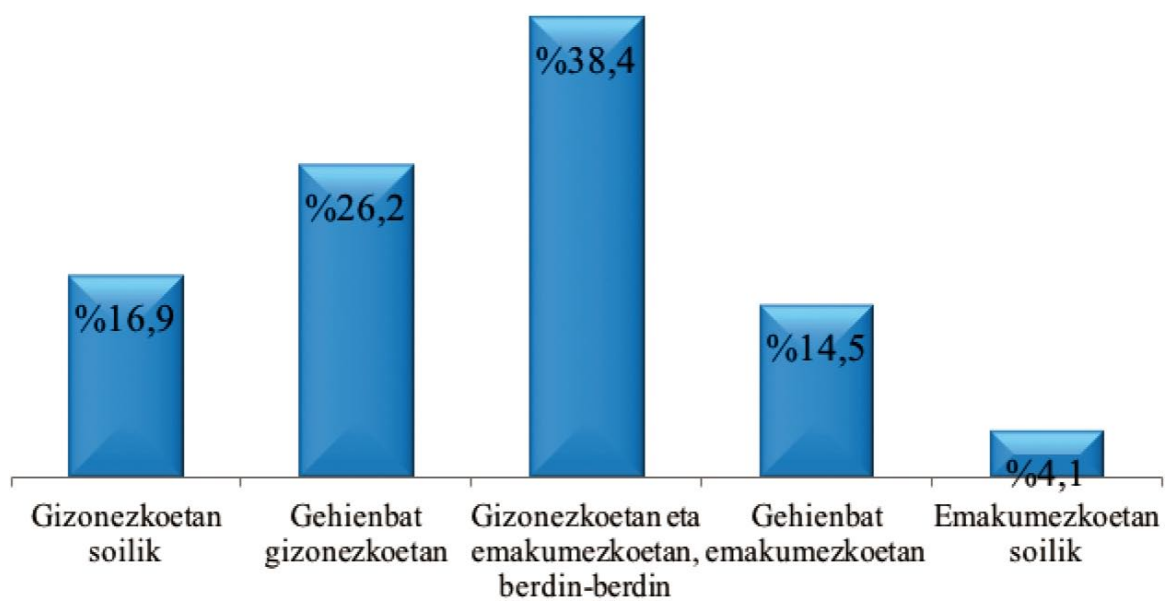

Iturria: geuk sortua.

Kontratazio berrietan generoari dagokionez nolako jokaera izan duten erakundeek gure ikerketako beste adierazle interesgarrietako bat da. $\mathrm{Hu}$ rrengo grafikoak elementu jakingarri bat islatzen du, gure iritziz: 2008tik 
hona kontratazioak egin dituzten Gipuzkoako erakundeen artean gizonezkoak kontratatzeko joera handiagoa egon da (\%16,9 eta \%26,2); gizonak eta emakumeak antzera kontratatu dituztenak \%38,4 dira eta gehienbat edo soilik emakumeak kontratatu dituztenak \%18,6.

Joera orokor horren barruan, ordea, bada zer komentatua ikerketan kontuan izan ditugun aldagaiei erreparatuz gero: gizonezkoak eta emakumezkoak berdintsu kontratatu dituzten enpresak gizarte ekonomiakoak direla.

\section{5. taula}

Kontratazio berrien profila forma juridikoa bereizita (\%)

G.9.2. Zer-nolako perfilak kontratatu dira?

\begin{tabular}{l|cccc}
\hline \multirow{2}{*}{\multicolumn{1}{c|}{ Kategoria }} & \multicolumn{4}{c}{ Forma juridikoa } \\
\cline { 2 - 5 } & $\begin{array}{c}\text { Elkarte } \\
\text { mugatua }\end{array}$ & $\begin{array}{c}\text { Akziokako } \\
\text { elkartea }\end{array}$ & $\begin{array}{c}\text { Gizarte } \\
\text { ekonomia }\end{array}$ & $\begin{array}{c}\text { Bestelako } \\
\text { elkartea }\end{array}$ \\
\hline Gizonezkoetan soilik & 26,4 & 12,9 & 6,3 & 4,5 \\
\hline Gehienbat gizonezkoetan & 22,2 & 40,3 & 18,8 & 4,5 \\
\hline $\begin{array}{l}\text { Gizonezkoetan eta emakumezkoe- } \\
\text { tan, berdin-berdin }\end{array}$ & 38,9 & 29,0 & 68,8 & 40,9 \\
\hline Gehienbat emakumezkoetan & 9,7 & 11,3 & 6,3 & 45,5 \\
\hline Emakumezkoetan soilik & 2,8 & 6,5 & 0,0 & 4,5 \\
\hline
\end{tabular}

Iturria: geuk sortua.

Nabarmendu beharreko beste ezaugarri bat da krisi urte hauetan gora egin duela lanaldi partzialeko kontratazioak. Europako beste herrialde batzuekin konparatuta, Euskadiko lanaldi partzialeko enpleguaren pisua txikia zen. Baina krisi garaian nabarmen egin du gora enplegu mota horrek eta lanaldi osoko hainbat eta hainbat lanpostu suntsitu dira. Lanaldi partzialeko kontratazioa lana banatzeko formula interesgarria izan daiteke ekonomiaren atzeraldiak gertatzen direnean; baina badira kontuan hartu beharreko bi alderdi oso garrantzitsu: nahitakotasuna, hau da, borondatezkoa izatea, eta tenporalitatea.

Landa-laneko 9.1. galderari: «2008. urteaz geroztik, zer-nolako kontratuak egin dira?» emandako erantzunak kontuan hartuta, esan daiteke Gipuzkoan inkestatutako hamar erakundetik ia zazpik egin dituzten kontratu 
berri ia guztiak lanaldi osokoak izan direla. Izan ere, erakundeen $\% 44,8 \mathrm{k}$ baieztatu dute lanaldi osoko kontratuak baino ez dituztela egin eta $\% 25 \mathrm{ek}$ gehienbat lanaldi osoko kontratuak egin dituztela.

\section{3. grafikoa}

Kontratazio berrietako lanaldi motak (\%)

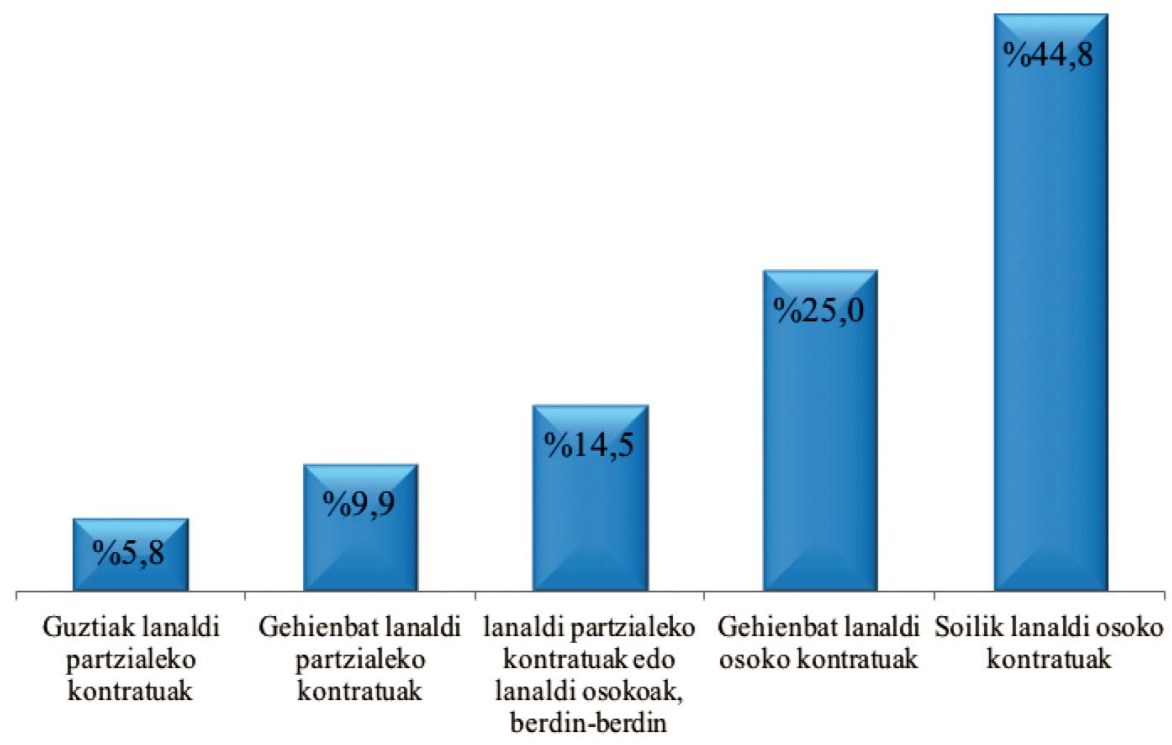

Iturria: geuk sortua.

Datuak erakusten dituenez, sozietate anonimoak dira jokabide hori indartu dutenak. Gizarte ekonomiako erakundeak, ordea, laginaren batez bestekotik behera daude lanaldi osoko kontratazioetan. 


\section{6. taula}

Kontratu motak forma juridikoa bereizita (\%)

G.9.1. Zer-nolako kontratuak?

\begin{tabular}{l|cccc}
\hline \multirow{2}{*}{ Kategoria } & \multicolumn{4}{|c}{ Forma juridikoa } \\
\cline { 2 - 5 } & $\begin{array}{c}\text { Elkarte } \\
\text { mugatua }\end{array}$ & $\begin{array}{c}\text { Akziokako } \\
\text { elkartea }\end{array}$ & $\begin{array}{c}\text { Gizarte } \\
\text { ekonomia }\end{array}$ & $\begin{array}{c}\text { Bestelako } \\
\text { elkartea }\end{array}$ \\
\hline Guztiak lanaldi partzialeko kontratuak & 5,6 & 4,8 & 0 & 13,6 \\
\hline $\begin{array}{l}\text { Gehienbat lanaldi partzialeko kontra- } \\
\text { tuak }\end{array}$ & 12,5 & 1,6 & 18,8 & 18,2 \\
\hline $\begin{array}{l}\text { lanaldi partzialeko kontratuak edo la- } \\
\text { naldi osokoak, berdin-berdin }\end{array}$ & 18,1 & 4,8 & 25 & 22,7 \\
\hline $\begin{array}{l}\text { Gehienbat lanaldi osoko kontratuak } \\
\text { Soilik lanaldi osoko kontratuak }\end{array}$ & 18,1 & 30,6 & 31,3 & 27,3 \\
\hline
\end{tabular}

Iturria: geuk sortua.

\section{Lan denboraren kudeaketa}

\subsection{LANALDia}

Gure landa-lanetik lortutako datuei erreparatuta, lanaldi 'tipikoa', hau da, egunean 7-8 ordukoa, da nagusia, Gipuzkoako enpresen \%46tan.

\section{4. grafikoa}

Lanaldiaren banaketa (\%) (hainbat erantzun)

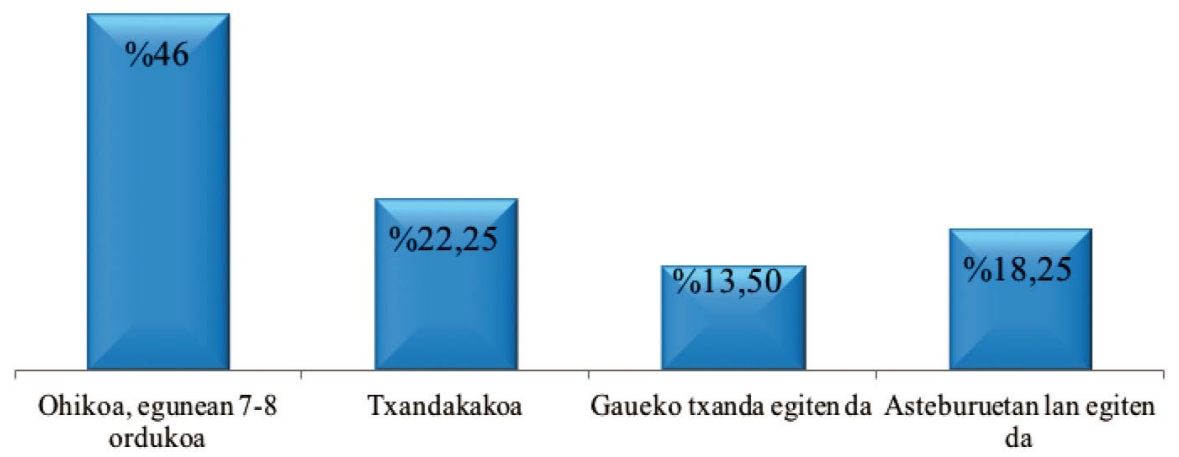

Iturria: geuk sortua. 


\section{7. taula}

Lanaldi motak forma juridikoa bereizita (\%)

G.1. Oro har, zein da zure erakundeko ohiko lanaldia?

\begin{tabular}{l|cccc}
\hline \multirow{2}{*}{\multicolumn{1}{c|}{ Kategoria }} & \multicolumn{4}{|c}{ Forma juridikoa } \\
\cline { 2 - 5 } & $\begin{array}{c}\text { Elkarte } \\
\text { mugatua }\end{array}$ & $\begin{array}{c}\text { Akziokako } \\
\text { elkartea }\end{array}$ & $\begin{array}{c}\text { Gizarte } \\
\text { ekonomia }\end{array}$ & $\begin{array}{c}\text { Bestelako } \\
\text { elkartea }\end{array}$ \\
\hline Ohikoa, egunean 7-8 ordukoa & 91,2 & 95,5 & 100,0 & 80,8 \\
Txandakakoa & 33,0 & 62,1 & 47,1 & 38,5 \\
Gaueko txanda egiten da & 14,3 & 40,9 & 29,4 & 34,6 \\
Asteburuetan lan egiten da & 36,3 & 30,3 & 29,4 & 57,7 \\
\hline
\end{tabular}

Iturria: geuk sortua.

Interesgarria da grafikoki irudikatzea nolako konbinazioak dauden Gipuzkoako erakundeetan lan denboraren kudeaketari dagokionez; izan ere, erakunde bakar batean hainbat lanaldi mota egon daitezke aldi berean. Grafikoan ikusten denez, erakundeen \%92tan ohiko lanaldia soilik dago; $\% 44,5$ etan, txandakako lanaldia dago; \%36,5etan, asteburuetan lan egiten da; eta \%27tan gaueko lanaldia dago.

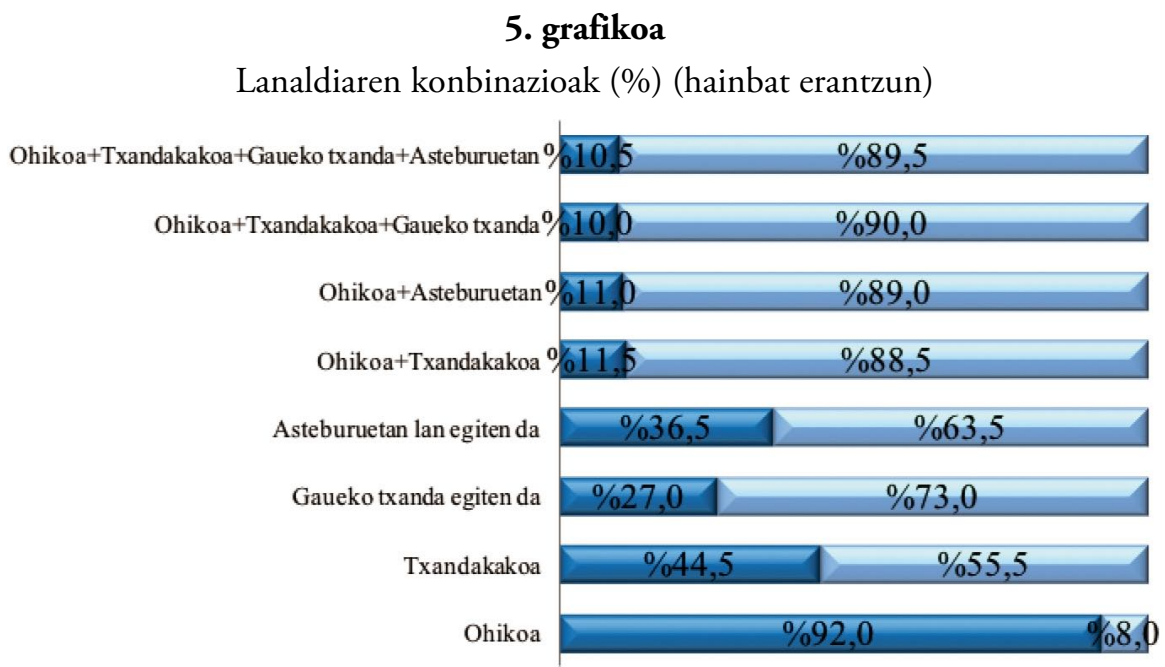

Iturria: geuk sortua. 


\subsection{Asteko LANORduaK}

Landa-laneko inkestako datuek erakutsi dutenaren arabera, ikerketan parte hartu duten erakundeen \%63tan asteko 40 orduko lanaldia dute ohiko lanaldi moduan.

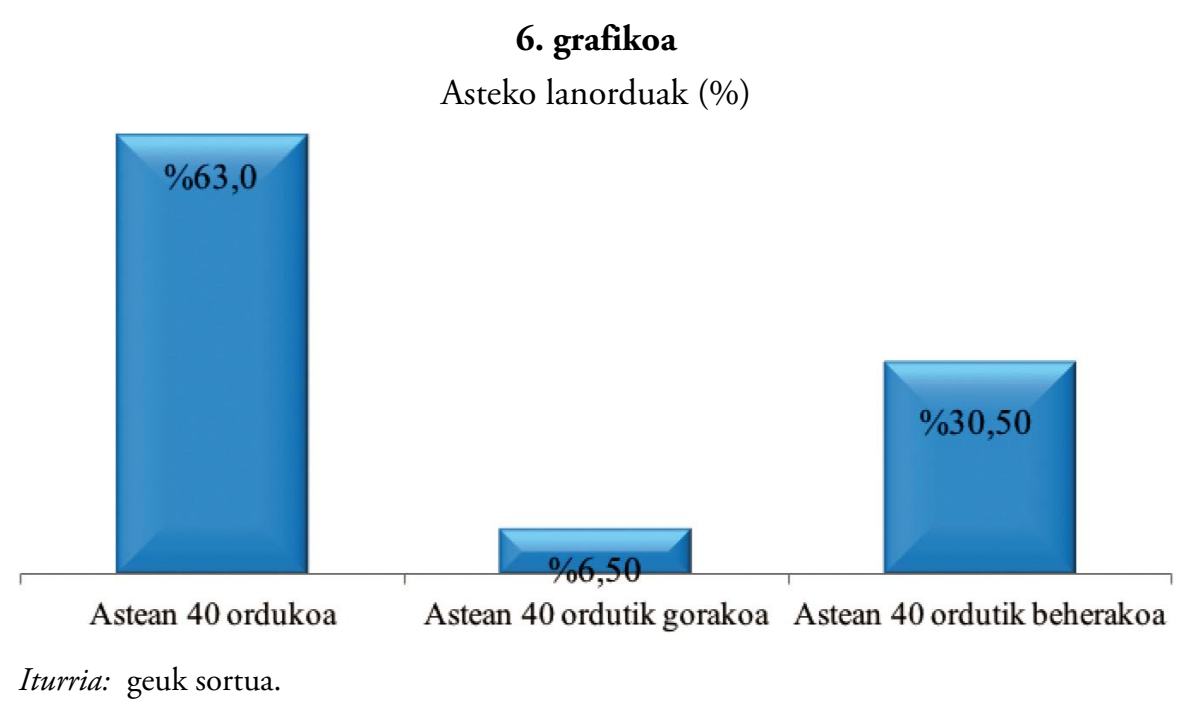

Gainera, asteko 40 orduko lanaldia da nagusia forma juridiko guztietako erakundeetan.

\section{8. taula}

Lanaldiaren iraupena forma juridikoa bereizita (\%)

G.2. Zenbatekoa da lanaldia?

\begin{tabular}{l|cccc}
\hline \multirow{2}{*}{\multicolumn{1}{c|}{ Kategoria }} & \multicolumn{4}{c}{ Forma juridikoa } \\
\cline { 2 - 5 } & $\begin{array}{c}\text { Elkarte } \\
\text { mugatua }\end{array}$ & $\begin{array}{c}\text { Akziokako } \\
\text { elkartea }\end{array}$ & $\begin{array}{c}\text { Gizarte } \\
\text { ekonomia }\end{array}$ & $\begin{array}{c}\text { Bestelako } \\
\text { elkartea }\end{array}$ \\
\hline Astean 40 ordukoa & 72,5 & 62,1 & 52,9 & 38,5 \\
Astean 40 ordutik gorakoa & 7,7 & 1,5 & 23,5 & 3,8 \\
Astean 40 ordutik beherakoa & 19,8 & 36,4 & 23,5 & 57,7 \\
\hline
\end{tabular}

Iturria: geuk sortua. 


\subsection{LAN DENBORAREN MURRIZKETAK}

Gure landa-laneko emaitzak aintzat hartuz gero, 2008tik hona Gipuzkoako erakundeetan ezarritako neurrien artean, lan denboraren murrizketa ez da izan oso garrantzitsua. Horrela, azken bost urteetan Gipuzkoako 10 erakundetik 8tan ez da ezarri lan denbora murrizteko inolako neurririk. Nabarmentzekoa da Gipuzkoako gizarte ekonomiako erakundeak direla lan denbora murrizteko neurria gutxien ezarri dutenak.

Lanaldiaren murrizketa motei buruzko 6.2. galderaren erantzunek erakusten digute lan denbora murrizteko hiru neurri mota hartu direla. Erakundeen \%15etan lanaldia laburtu da, \%8tan jaiegun gehiago hartu dira eta $\% 5,5$ etan oporrak luzatu dira.

\section{7. grafikoa}

Lan denboraren murrizketa motak (\%) (hainbat erantzun)

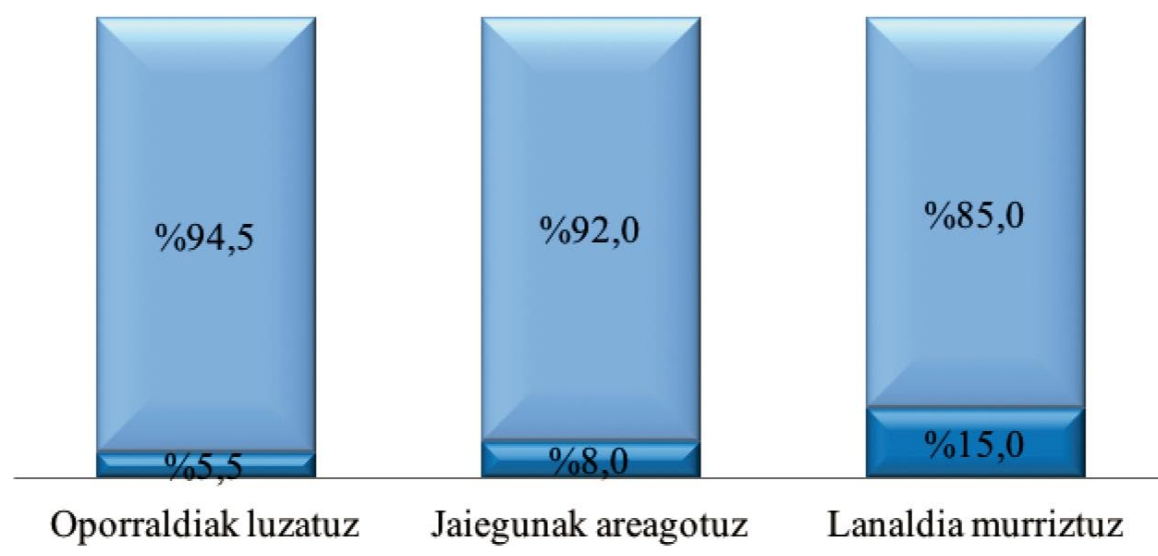

घí $\square$ No

Iturria: geuk sortua.

6.1. galderan enpresei galdetu zitzaien ea lan denboraren murrizketak aldaketarik ekarri dion langileen soldatari eta emaitzek diote lan denbora murrizteko neurriren bat ezarri duten Gipuzkoako erakundeen artean $(\% 20,5)$, bi herenetan baino gehiagotan horrek ez duela soldataren aldaketarik ekarri, eta datua antzekoa da erakundeen forma juridikoa gorabehera. 


\section{9. taula}

Lan denboraren aldaketa motak forma juridikoa bereizita (\%)

G.6. 2008. urteaz geroztik, zure erakundean kontratazio berririk egin al da?

\begin{tabular}{l|cccc}
\hline \multirow{2}{*}{ Kategoria } & \multicolumn{4}{|c}{ Forma juridikoa } \\
\cline { 2 - 5 } & $\begin{array}{c}\text { Elkarte } \\
\text { mugatua }\end{array}$ & $\begin{array}{c}\text { Akziokako } \\
\text { elkartea }\end{array}$ & $\begin{array}{c}\text { Gizarte } \\
\text { ekonomia }\end{array}$ & $\begin{array}{c}\text { Bestelako } \\
\text { elkartea }\end{array}$ \\
\hline Oporraldia luzatuz & 7,7 & 3,0 & 0,0 & 7,7 \\
Jaiegunak areagotuz & 7,7 & 10,6 & 5,9 & 3,8 \\
Lanaldia murriztuz & 11,0 & 18,2 & 5,9 & 26,9 \\
\hline
\end{tabular}

Iturria: geuk sortua.

\subsection{ENPRESAREN ETA LANGILEEN ETA HAIEN ORDEZKARIEN ARTEKO AKORDIOAK}

Gipuzkoako erakundeetan, krisi ekonomikoko urteetan, lan denboraren kudeaketan kontuan hartu dugun beste adierazle bat izan da ea enpresaren eta langileen eta haien ordezkarien artean akordiorik lortu den lan denbora murrizteko.

Datuka ikusita, kasuen ia \%80tan ez da akordiorik izan eta \%20,5etan, berriz, akordioetara iritsi dira. Datua berdina da, gainera, nortasun juridiko guztietako erakundeetan.

\section{0. taula}

Enpresaren eta langileen arteko akordioak forma juridikoa bereizita (\%)

G.7. Zure enpresan, krisiaren eraginez, lan-denbora murrizteko akordiorik adostu da langileekin edota horien ordezkariekin?

\begin{tabular}{c|cccc}
\hline \multirow{2}{*}{ Kategoria } & \multicolumn{4}{|c}{ Forma juridikoa } \\
\cline { 2 - 5 } & $\begin{array}{c}\text { Elkarte } \\
\text { mugatua }\end{array}$ & $\begin{array}{c}\text { Akziokako } \\
\text { elkartea }\end{array}$ & $\begin{array}{c}\text { Gizarte } \\
\text { ekonomia }\end{array}$ & $\begin{array}{c}\text { Bestelako } \\
\text { elkartea }\end{array}$ \\
\hline Bai & 19,8 & 28,8 & 11,8 & 7,7 \\
Ez & 80,2 & 71,2 & 88,2 & 92,3 \\
\hline
\end{tabular}

Iturria: geuk sortua. 


\subsection{Aparteko lanorduak}

Aparteko lanorduei dagokienez, landa-laneko emaitzek erakusten dute Gipuzkoako erakundeen \%19tan ohikoa dela aparteko orduak egitea eta \%81 etan ez dela ohikoa. Aipatu beharrekoa da Gipuzkoako gizarte ekonomiako erakundeen artean ohikoagoak direla aparteko lanorduak eta sozietate anonimoetan, berriz, aparteko lanordu gutxiago egiten dela.

\section{1. taula}

Aparteko lanorduak, forma juridikoa bereizita (\%)

G.3. Zure erakundean aparteko orduak ohikoak dira? Bai

\begin{tabular}{cccc}
\hline \multicolumn{4}{c}{ Forma juridikoa } \\
\hline Elkarte mugatua & Akziokako elkartea & Gizarte ekonomia & Bestelako elkartea \\
\hline 19,8 & 12,1 & 41,2 & 19,2 \\
\hline
\end{tabular}

Iturria: geuk sortua.

Lanaldietan aparteko lanorduak egin ohi dituztenen artean (\%19), $\% 60,5$ etan ordaindu edo konpentsatu egiten dira (konpentsatu, adibidez, ordu poltsekin).

\section{8. grafikoa}

Aparteko lanordu motak (hainbat erantzun) (\%)

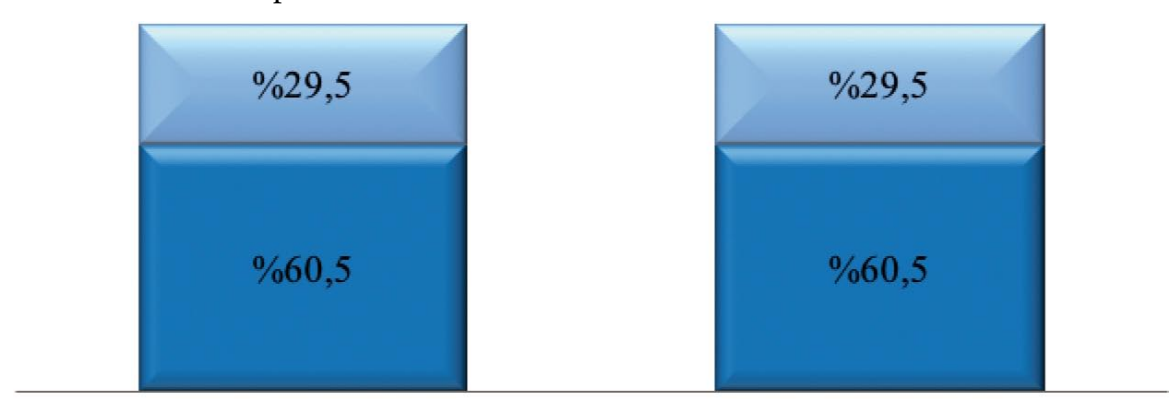

Ordainduak

Konpentsatuak

Iturria: geuk sortua. 
Eta Gipuzkoako erakunde motei dagokienez, gizarte ekonomiakoek jotzen dute gehien aparteko lanorduak konpentsatzera, eta sozietate anonimoek eta erantzukizun mugatukoek, aldiz, aparteko orduak ordaintzea hautatzen dute.

\section{2. taula}

Aparteko lanordu motak forma juridikoa bereizita (\%)

G.3.1. Eta aparteko ordu horiek dira ...

\begin{tabular}{l|cccc}
\hline \multirow{2}{*}{\multicolumn{1}{c|}{ Kategoria }} & \multicolumn{4}{|c}{ Forma juridikoa } \\
\cline { 2 - 5 } & $\begin{array}{c}\text { Elkarte } \\
\text { mugatua }\end{array}$ & $\begin{array}{c}\text { Akziokako } \\
\text { elkartea }\end{array}$ & $\begin{array}{c}\text { Gizarte } \\
\text { ekonomia }\end{array}$ & $\begin{array}{c}\text { Bestelako } \\
\text { elkartea }\end{array}$ \\
\hline Ordainduak & 77,8 & 100 & 14,3 & 0 \\
Konpentsatuak & 44,4 & 75 & 71,4 & 80 \\
\hline
\end{tabular}

Iturria: geuk sortua.

Gipuzkoako enpresetako aparteko lanorduen erabilerari buruzko beste puntu interesgarri bat da ea aparteko lanorduak eteteko akordiorik dagoen. Eta lortutako informazioa argi adierazten du ez dagoela halako akordiorik kasuen \%95etan.

\section{3. taula}

Aparteko lanordu motak forma juridikoa bereizita (\%)

G.8. Zure erakundean bada aparteko orduak desagerrarazteko akordioren bat? Bai

\begin{tabular}{cccc}
\hline \multicolumn{4}{c}{ Forma juridikoa } \\
\hline Elkarte mugatua & Akziokako elkartea & Gizarte ekonomia & Bestelako elkartea \\
\hline 3,3 & 7,6 & 5,9 & 3,8 \\
\hline
\end{tabular}

Iturria: geuk sortua.

Gainera, aparteko lanorduak eteteko akordioren bat izan duten enpresen artean (\%5), \%30etan kontratazio berriak egin dira. 


\subsection{LANALDI TRINKOTUA}

Azkenik, lanaldi trinkotuari erreparatuko diogu. Neurri honek aparteko interesa du gure proiektuan, uste baitugu egokia dela lana banatzeko. Gure landa-laneko emaitzek erakusten dute Gipuzkoako hamar erakundetik bitan baino pixka bat gehiagotan lan aste trinkoak erabili direla azken bost urteetan.

\section{4. taula}

Lanaldi trinkotua forma juridikoa kontutan hartuta (\%)

G.5. Zure erakundean lan-aste trinkoko sistemak erabiltzen dira? Bai

\begin{tabular}{cccc}
\hline \multicolumn{4}{c}{ Forma juridikoa } \\
\hline Elkarte mugatua & Akziokako elkartea & Gizarte ekonomia & Bestelako elkartea \\
\hline 20,9 & 21,2 & 17,6 & 23,1 \\
\hline
\end{tabular}

Iturria: geuk sortua.

\section{9. grafikoa}

Lanaldia trinkotzeko sistemetan aritutako pertsonak, generoaren arabera

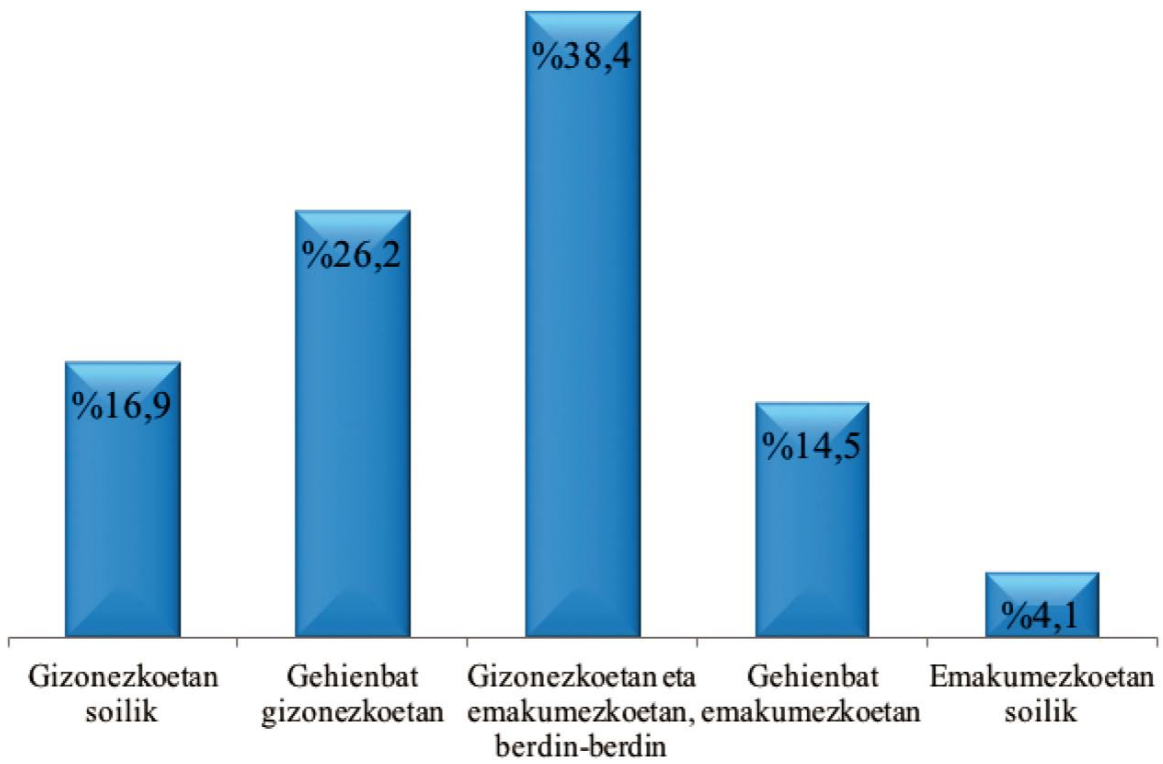

Iturria: geuk sortua. 
Bestalde, lan asteak trinkotzeko sistemak praktikara eraman dituzten enpresa horietatik (\%21), \%38,4k diote antzera aplikatu dituztela halako neurriak gizonezkoen zein emakumezkoen artean; beraz, pentsa liteke neurri mota hau ez dagoela generoarekin lotuta. Ikerketa honetan parte hartu duten Gipuzkoako erakundeetako langileak, baina, gizonezkoak dira gehienbat eta horrek markatzen du neurri honen orientazioa.

\section{5. taula}

Lanaldia trinkotzeko sistemetan aritutako pertsonak, generoaren arabera forma juridikoa kontutan hartuta (\%)

G.5.1. Zein perfiletan aplikatu da neurri hori?

\begin{tabular}{l|cccc}
\hline \multirow{2}{*}{\multicolumn{1}{c|}{ Kategoria }} & \multicolumn{4}{c}{ Forma juridikoa } \\
\cline { 2 - 5 } & $\begin{array}{c}\text { Elkarte } \\
\text { mugatua }\end{array}$ & $\begin{array}{c}\text { Akziokako } \\
\text { elkartea }\end{array}$ & $\begin{array}{c}\text { Gizarte } \\
\text { ekonomia }\end{array}$ & $\begin{array}{c}\text { Bestelako } \\
\text { elkartea }\end{array}$ \\
\hline Gizonezkoetan soilik & 5,3 & 0,0 & 0 & 0 \\
\hline Gehienbat gizonezkoetan & 15,8 & 14,3 & 0 & 0 \\
\hline $\begin{array}{l}\text { Gizonezkoetan eta emakumezkoe- } \\
\text { tan, berdin-berdin }\end{array}$ & 73,7 & 85,7 & 100 & 100 \\
\hline Gehienbat emakumezkoetan & 5,3 & 0,0 & 0 & 0 \\
\hline Emakumezkoetan soilik & 0,0 & 0,0 & 0 & 0 \\
\hline
\end{tabular}

Iturria: geuk sortua.

\section{0. grafikoa}

Kontratazio partzial berriak lanaldia trinkotzeko sistemen ondorioz (\%)

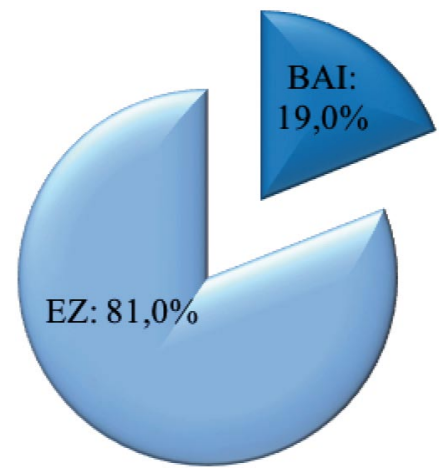

Iturria: geuk sortua. 
Lanaldia trinkotzeko sistemak erabili dituzten erakundeen artean (\%21), \%19k adierazi dute trinkotze horren ondorioz kontratazio partzial berriak sortu direla.

\section{6. taula}

Kontratazio partzial berriak lanaldia trinkotzeko sistemen ondorioz forma juridikoa kontutan hartuta (\%)

G.5.2. Horren ondorioz, lanaldi partzialeko kontratazio gehiago sortu dira? Bai

\begin{tabular}{cccc}
\hline \multicolumn{4}{c}{ Forma juridikoa } \\
\hline Elkarte mugatua & Akziokako elkartea & Gizarte ekonomia & Bestelako elkartea \\
\hline 21,1 & 7,1 & 66,7 & 16,7 \\
\hline
\end{tabular}

Iturria: geuk sortua.

\section{Baimenak}

Lana banatzeko neurrien artean, bi baimen mota hartu ditugu aintzat: eszedentziak eta lanaldiaren aldi baterako murrizketak, horiek izan direlako erabilienak krisi urte hauetan erakundeetan lana mantentzeko edo banatzeko.

\subsection{LANALDIAREN ALDI BATERAKO MURRIZKETAK}

Landa-laneko emaitzen arabera, Gipuzkoako hiru erakundetik ia batean lanaldiaren aldi baterako murrizketak egin dira 2008. urteaz geroztik. Gainera, badirudi neurri hori gehiago erabili dela erakunde handietan, hau da, 50 langiletik gorakoetan, nortasun juridikoa edozein dela ere.

\section{7. taula}

Lanaldiaren murrizketak forma juridikoa kontutan hartuta (\%)

G.13. Zure erakundean lanaldiak aldi batez murriztu dira? Bai

\begin{tabular}{cccc}
\hline \multicolumn{4}{c}{ Forma juridikoa } \\
\hline Elkarte mugatua & Akziokako elkartea & Gizarte ekonomia & Bestelako elkartea \\
\hline 31,9 & 34,8 & 23,5 & 34,6 \\
\hline
\end{tabular}

Iturria: geuk sortua. 
Lanaldiaren aldi baterako murrizketak egin dituzten Gipuzkoako erakundeen artean $(\% 32,5)$, haurrak zaintzea izan da arrazoi nagusia $(\% 83,1)$, hurrengo grafikoak erakusten duenez. Hala da, erakundeen nortasun juridikoa edozein dela ere.

\section{1. grafikoa}

Lanaldia murrizteko arrazoiak (\%) (hainbat erantzun)

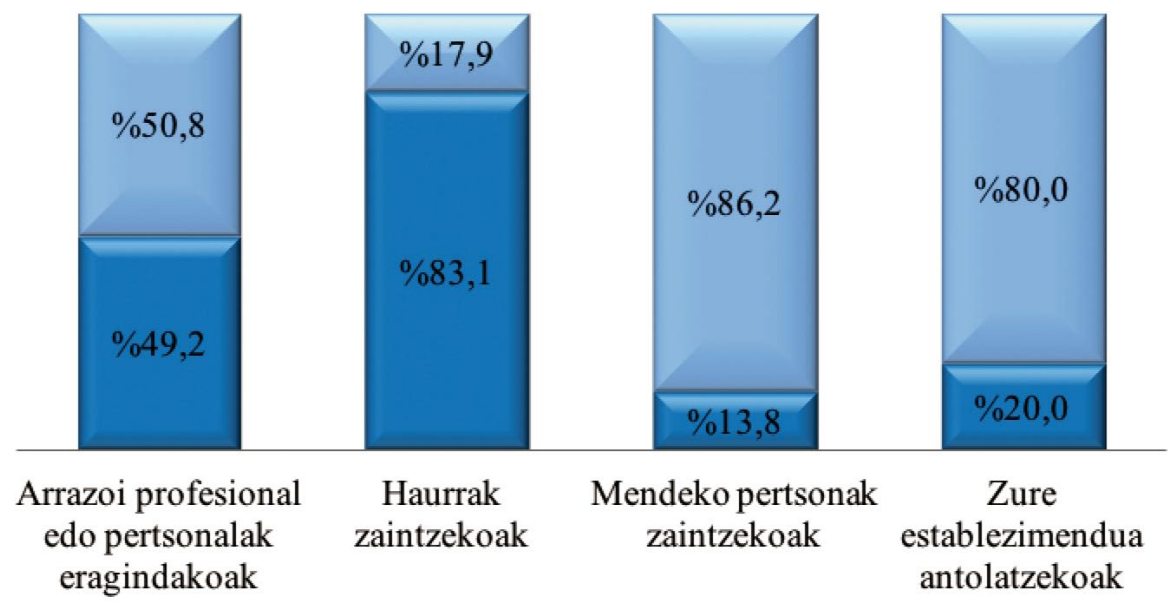

QSí $\square$ No

Iturria: geuk sortua.

\section{8. taula}

Lanaldia murrizteko arrazoiak forma juridikoa kontutan hartuta (\%)

G.13.1. Zein motakoak izan dira?

\begin{tabular}{l|cccc}
\hline \multirow{2}{*}{ Kategoria } & \multicolumn{4}{|c}{ Forma juridikoa } \\
\cline { 2 - 6 } & $\begin{array}{c}\text { Elkarte } \\
\text { mugatua }\end{array}$ & $\begin{array}{c}\text { Akziokako } \\
\text { elkartea }\end{array}$ & $\begin{array}{c}\text { Gizarte } \\
\text { ekonomia }\end{array}$ & $\begin{array}{c}\text { Bestelako } \\
\text { elkartea }\end{array}$ \\
\hline $\begin{array}{l}\text { Arrazoi profesional edo pertsonalak } \\
\text { eragindakoak }\end{array}$ & 41,4 & 60,9 & 50 & 44,4 \\
\hline Haurrak zaintzekoak & 89,7 & 73,9 & 75 & 88,9 \\
\hline Mendeko pertsonak zaintzekoak & 10,3 & 17,4 & 0 & 22,2 \\
\hline Zure establezimendua antolatzekoak & 20,7 & 26,1 & 25 & 0,0 \\
\hline
\end{tabular}

Iturria: geuk sortua. 
Neurri hau erabili duten enpresetako pertsonen generoari erreparatuz gero, emakumeak dira gehienak. Zalantzarik gabe, neurri honetan parte hartu duten gehienak emakumeak izatea estuki lotuta dago murrizketa eskatzeko arrazoi nagusiarekin: alegia, haurrak zaintzearekin.

\section{2. grafikoa}

Lanaldiaren murrizketak generoaren arabera (\%)

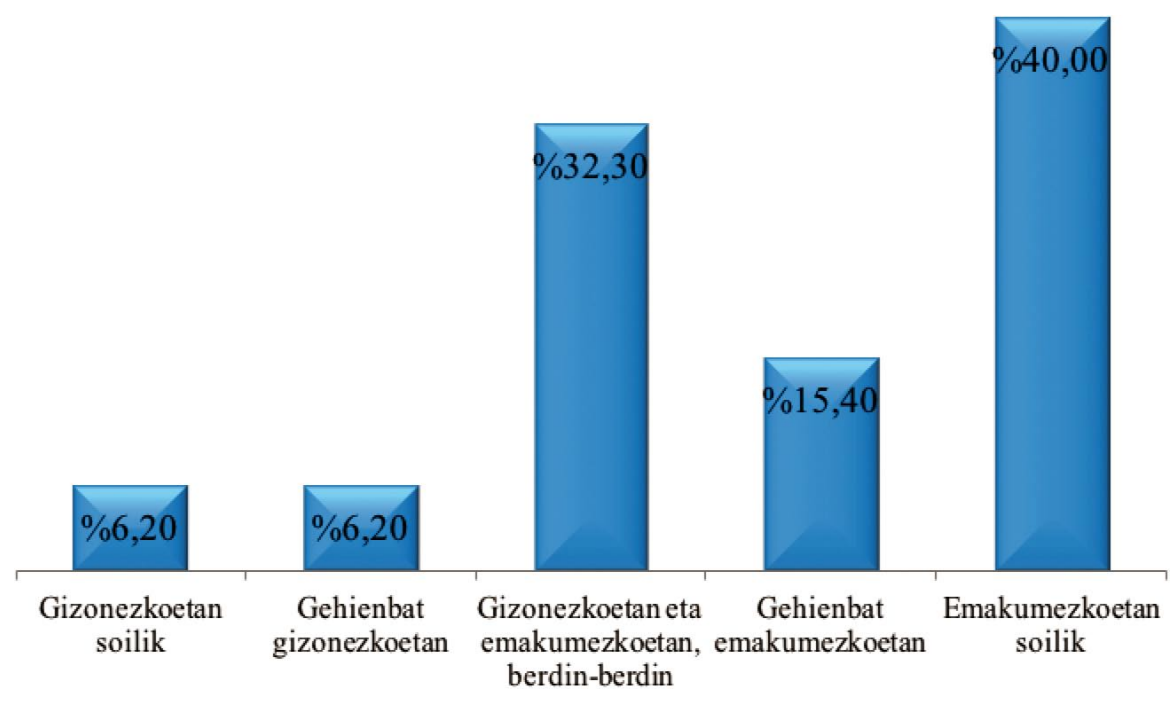

Iturria: geuk sortua.

Lanaldiaren murrizketak egin diren Gipuzkoako erakundeen barruan $(\% 32,5), \% 60 \tan$ ez da kontratazio berririk egin lanaldien murrizketak estaltzeko. Eta azkenik, kontratazioak egin dituzten enpresen artean (\%32,5en \%40), \%57,7k aitortu dute kontratazio horiek partzialak izan direla. 


\section{9. taula}

Lanaldiaren murrizketak generoaren arabera forma juridikoa kontutan hartuta (\%) G.13.2. Zein perfiletan aplikatu da neurri hori?

\begin{tabular}{l|cccc}
\hline \multirow{2}{*}{\multicolumn{1}{c|}{ Kategoria }} & \multicolumn{4}{c}{ Forma juridikoa } \\
\cline { 2 - 5 } & $\begin{array}{c}\text { Elkarte } \\
\text { mugatua }\end{array}$ & $\begin{array}{c}\text { Akziokako } \\
\text { elkartea }\end{array}$ & $\begin{array}{c}\text { Gizarte } \\
\text { ekonomia }\end{array}$ & $\begin{array}{c}\text { Bestelako } \\
\text { elkartea }\end{array}$ \\
\hline Gizonezkoetan soilik & 3,4 & 13,0 & 0 & 0,0 \\
\hline Gehienbat gizonezkoetan & 10,3 & 4,3 & 0 & 0,0 \\
\hline $\begin{array}{l}\text { Gizonezkoetan eta emakumezkoe- } \\
\text { tan, berdin-berdin }\end{array}$ & 27,6 & 39,1 & 50 & 22,2 \\
\hline Gehienbat emakumezkoetan & 17,2 & 8,7 & 25 & 22,2 \\
\hline Emakumezkoetan soilik & 41,4 & 34,8 & 25 & 55,6 \\
\hline
\end{tabular}

Iturria: geuk sortua.

\subsection{ESZENDENTZIAK}

Landa-lanak eszedentziei buruz emandako datuen arabera, eszedentzien egoera eta bilakaera Gipuzkoako erakundeetan lanaldiaren aldi baterako murrizketena bezalakotsua da. Gipuzkoako enpresen \%34,5etan egon dira eszedentziak azken bost urteetan. Dena dela, badirudi eszedentziak gehiago erabili direla gizarte ekonomiako erakundeetan.

\section{0. taula}

Eszedentziak forma juridikoa kontutan hartuta (\%)

G.12. Zure erakundean eszedentziarik eman da erreferentziazko epealdi honetan? Bai

\begin{tabular}{cccc}
\hline \multicolumn{3}{c}{ Forma juridikoa } \\
\hline Elkarte mugatua & Akziokako elkartea & Gizarte ekonomia & Bestelako elkartea \\
\hline 27,5 & 24,2 & 76,5 & 57,7 \\
\hline
\end{tabular}

Iturria: geuk sortua.

Lanaldiaren aldi baterako murrizketetan bezala, haurrak zaintzea izan da eszedentzien arrazoi nagusietako bat, eszedentziak eman dituzten Gi- 
puzkoako erakundeetan $(\% 34,5)$. Baina badira beste motibo indartsu batzuk: arrazoi pertsonalak edo profesionalak.

\section{3. grafikoa}

Eszedentzien arrazoiak (\%) (hainbat erantzun)

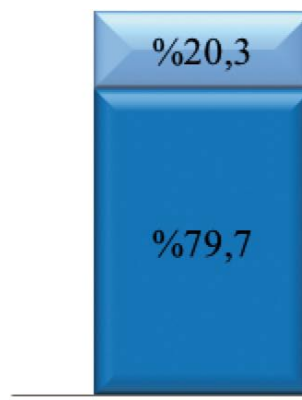

Arrazoi profesional edo pertsonalak eragindakoak

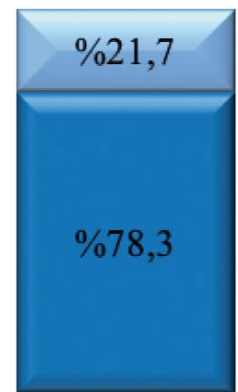

Haurrak zaintzekoak

Q $\mathbf{S i ́}$ No

Iturria: geuk sortua.

\section{1. taula}

Eszedentzien arrazoiak forma juridikoa kontutan hartuta (\%)

G.12.1. Zein motakoak?

\begin{tabular}{l|cccc}
\hline \multirow{2}{*}{ Kategoria } & \multicolumn{4}{|c}{ Forma juridikoa } \\
\cline { 2 - 5 } & $\begin{array}{c}\text { Elkarte } \\
\text { mugatua }\end{array}$ & $\begin{array}{c}\text { Akziokako } \\
\text { elkartea }\end{array}$ & $\begin{array}{c}\text { Gizarte } \\
\text { ekonomia }\end{array}$ & $\begin{array}{c}\text { Bestelako } \\
\text { elkartea }\end{array}$ \\
\hline $\begin{array}{l}\text { Arrazoi profesional edo pertsona- } \\
\text { lak eragindakoak }\end{array}$ & 84 & 68,8 & 84,6 & 80,0 \\
\hline Haurrak zaintzekoak & 76 & 75,0 & 84,6 & 80,0 \\
\hline Mendeko pertsonak zaintzekoak & 16 & 18,8 & 30,8 & 6,7 \\
\hline
\end{tabular}

Iturria: geuk sortua.

Eszedentziak eman dituzten erakunde gipuzkoarren artean $(\% 34,5)$, $\% 75,4 \mathrm{k}$ diote kontratazio berriak egin dituztela eszedentzia horiek estaltzeko, eta gehienetan horixe dela ohiko jokabidea. 


\section{4. grafikoa}

Eszedentziak generoaren arabera (\%)

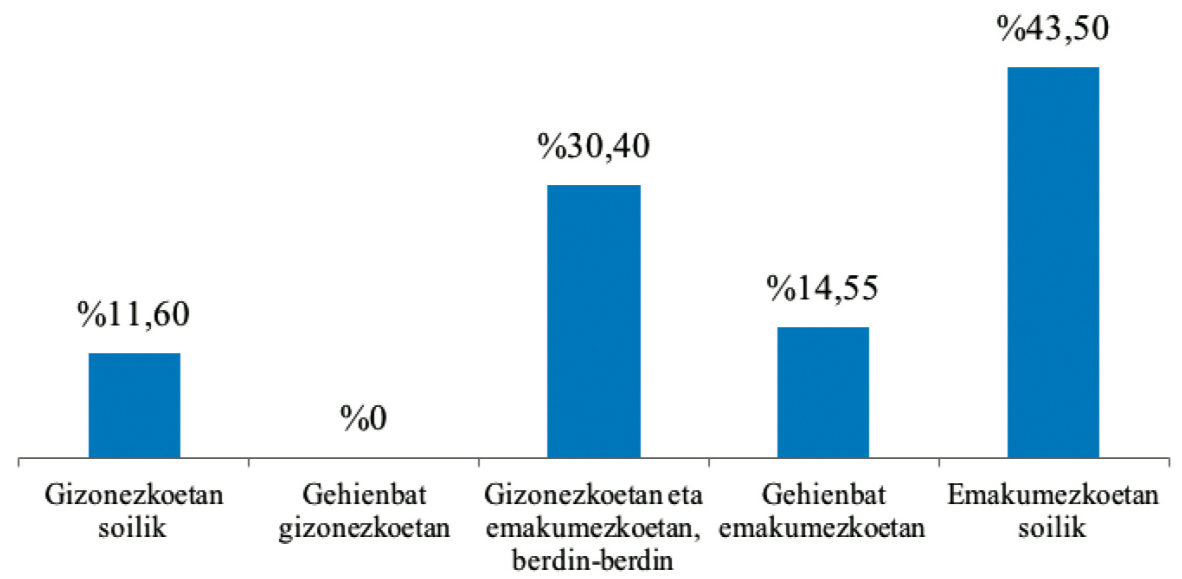

Iturria: geuk sortua.

\section{2. taula}

Eszedentziak generoaren arabera forma juridikoa kontutan hartuta (\%) G.12.2. Zein perfiletan aplikatu da neurri hori?

\begin{tabular}{l|cccc}
\hline \multirow{2}{*}{\multicolumn{1}{c|}{ Kategoria }} & \multicolumn{4}{c}{ Forma juridikoa } \\
\cline { 2 - 5 } & $\begin{array}{c}\text { Elkarte } \\
\text { mugatua }\end{array}$ & $\begin{array}{c}\text { Akziokako } \\
\text { elkartea }\end{array}$ & $\begin{array}{c}\text { Gizarte } \\
\text { ekonomia }\end{array}$ & $\begin{array}{c}\text { Bestelako } \\
\text { elkartea }\end{array}$ \\
\hline Gizonezkoetan soilik & 4 & 25,0 & 15,4 & 6,7 \\
\hline Gehienbat gizonezkoetan & 0 & 0,0 & 0,0 & 0,0 \\
\hline $\begin{array}{l}\text { Gizonezkoetan eta emakumezkoe- } \\
\text { tan, berdin-berdin }\end{array}$ & 20 & 31,3 & 46,2 & 33,3 \\
\hline Gehienbat emakumezkoetan & 8 & 12,5 & 15,4 & 26,7 \\
\hline Emakumezkoetan soilik & 68 & 31,3 & 23,1 & 33,3 \\
\hline
\end{tabular}

Iturria: geuk sortua.

Eta azkenik, kontratazioak egin dituzten enpresen artean $(\% 34,5$ en $\% 75,4), \% 46,2 \mathrm{k}$ aitortu dute kontratazio horiek partzialak izan direla. 


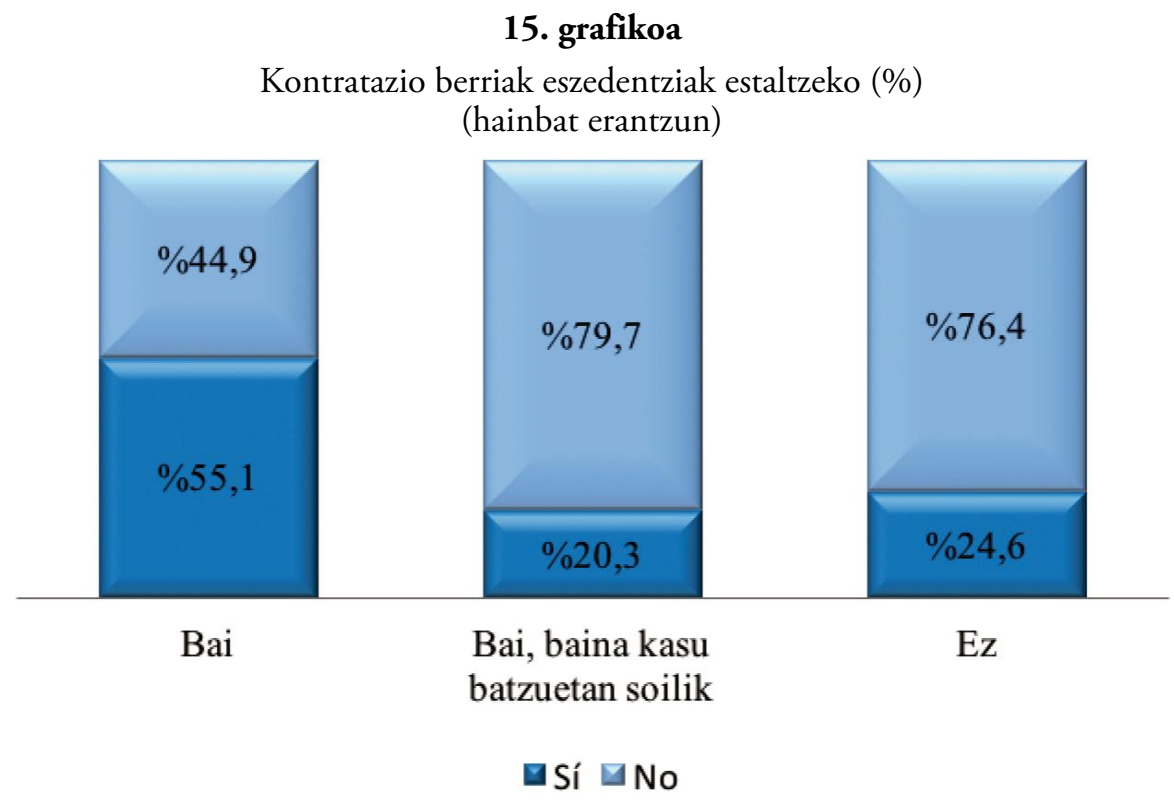

Iturria: geuk sortua.

\section{3. taula}

Kontratazio berriak eszedentziak estaltzeko forma juridikoa kontutan hartuta (\%)

G.12.3. Eszedentzia horiek betetzeko kontratazio berriak egin dira?

\begin{tabular}{l|cccc}
\hline \multirow{2}{*}{ Kategoria } & \multicolumn{4}{c}{ Forma juridikoa } \\
\cline { 2 - 5 } & $\begin{array}{c}\text { Elkarte } \\
\text { mugatua }\end{array}$ & $\begin{array}{c}\text { Akziokako } \\
\text { elkartea }\end{array}$ & $\begin{array}{c}\text { Gizarte } \\
\text { ekonomia }\end{array}$ & $\begin{array}{c}\text { Bestelako } \\
\text { elkartea }\end{array}$ \\
\hline $\begin{array}{l}\text { Bai, gure erakundean ohikoa da } \\
\text { hori egitea }\end{array}$ & 52 & 37,5 & 53,8 & 80 \\
\hline Bai, baina kasu batzuetan soilik & 8 & 25,0 & 38,5 & 20 \\
\hline Ez & 40 & 37,5 & 7,7 & 0 \\
\hline
\end{tabular}

Iturria: geuk sortua. 


\subsection{Prestakuntzarako BaimenaK EDO BAIMEN PARTZIALKI ORDAinduAK}

Atal hau bukatzeko, gure landa-laneko ikergai diren Gipuzkoako erakundeetan prestakuntzarako baimenen edo baimen partzialki ordainduen egoera eta bilakaera zein den aurkeztuko dugu. Landa-lanaren emaitzek erakusten dute erakundeen $\% 57,5 \mathrm{ek}$ eman dituztela halako baimenak. Berriz ere, gizarte ekonomiako erakundeek datu altuagoak ematen dituzte.

\section{4. taula}

Prestakuntzarako baimenak edo baimen partzialki ordainduak forma juridikoa kontutan hartuta (\%)

G.14. Zure erakundean prestakuntza jasotzeko baimenak edo partzialki ordainduak eman dira? Bai

\begin{tabular}{cccc}
\hline \multicolumn{4}{c}{ Forma juridikoa } \\
\hline Elkarte mugatua & Akziokako elkartea & Gizarte ekonomia & Bestelako elkartea \\
\hline 56 & 53 & 70,6 & 65,4 \\
\hline
\end{tabular}

Iturria: geuk sortua.

\section{6. grafikoa}

Prestakuntzarako baimenak edo baimen partzialki ordainduak generoaren arabera $(\%)$

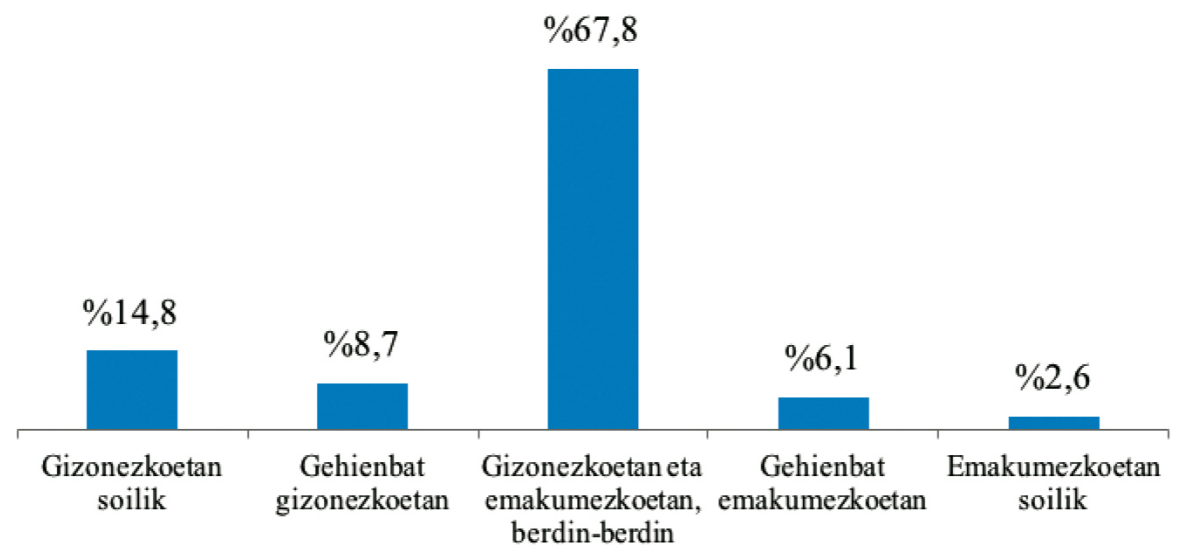

Iturria: geuk sortua.

Prestakuntzarako baimenak eman dituzten Gipuzkoako erakundeetan $(\% 57,5)$, lanaldiaren aldi baterako murrizketetan eta eszedentzietan ikusi du- 
gun emakumeen protagonismorik ez dago, hurrengo grafikoak erakusten digunaren arabera. Neurri honetan generoen arteko parekotasuna dago kasuen $\% 67,8$ tan, berdintsu, gainera, nortasun juridiko guztietako erakundeetan.

Bestalde, prestakuntzarako baimenak edo baimen partzialki ordainduak eman diren Gipuzkoako erakundeetan $(\% 57,5)$, hamarretik zortzitan baino zerbait gehiagotan $(\% 81,7)$ ez da kontratazio berririk egin.

\section{5. taula}

Kontratazio berriak prestakuntzarako baimenak edo baimen partzialki ordainduak estaltzeko forma juridikoa kontutan hartuta (\%)

G.14.2. Baimen horiek betetzeko kontratazio berriak egin dira?

\begin{tabular}{l|cccc}
\hline \multirow{2}{*}{ Kategoria } & \multicolumn{4}{|c}{ Forma juridikoa } \\
\cline { 2 - 5 } & $\begin{array}{c}\text { Elkarte } \\
\text { mugatua }\end{array}$ & $\begin{array}{c}\text { Akziokako } \\
\text { elkartea }\end{array}$ & $\begin{array}{c}\text { Gizarte } \\
\text { ekonomia }\end{array}$ & $\begin{array}{c}\text { Bestelako } \\
\text { elkartea }\end{array}$ \\
\hline $\begin{array}{l}\text { Bai, gure erakundean ohikoa da } \\
\text { hori egitea }\end{array}$ & 3,9 & 5,7 & 25,0 & 11,8 \\
\hline Bai, baina kasu batzuetan soilik & 11,8 & 5,7 & 8,3 & 17,6 \\
\hline Ez & 84,3 & 88,6 & 66,7 & 70,6 \\
\hline
\end{tabular}

Iturria: geuk sortua.

\section{Enplegua banatzeko neurriak erakundearen arrazoiak direla eta}

Krisialdian, erakundeek zenbait barne irtenbide planteatu dituzte langileak langabezian ez geratzeko. Honelako neurriak, esaterako: langileak beste lantegi batzuetara mugitzea; oporrak luzatzea; lanaldia aldi baterako laburtzea, hainbatetan EEEa bihurtu dena; erretiro aurreratuak ematea... Halako neurriak arrunt erabili dira gizarte ekonomiako erakundeen kudeaketan ekonomiaren zikloa gorabehera. Haatik, erakunde mota guztiak hartuta, langabezia saihesteko neurririk erabiliena krisi urte hauetan EEEa izan da.

\subsection{ENPLEgua ERREgulatZeKo ESPEDiENTEAK}

Era bateko eta besteko EEEak aplikatu dira erakundeek krisian bizi izandako egoeraren arabera. Etete EEEa da lanaldiaren aldi baterako murrizketarako gehien erabili den neurria, langabezia saiheste aldera; baina kasu batzuetan azkenean etete espedientea iraungitze espediente bilakatu da. 
Gure landa-laneko datuei erreparatuta, Gipuzkoako lau erakundetik ia batek dio EEE motaren bat aplikatu duela 2008tik hona; hau da, ikertutako erakundeen $\% 24 \mathrm{k}$. Neurri horrek eragin handiagoa izan du industriako eta eraikuntzako erakundeetan.

\section{6. taula}

Enplegua erregulatzeko espedienteak forma juridikoa kontutan hartuta (\%)

G.11. Krisialdi honetan zure erakundean EEE motaren bat aplikatu da? Bai

\begin{tabular}{cccc}
\hline \multicolumn{4}{c}{ Forma juridikoa } \\
\hline Elkarte mugatua & Akziokako elkartea & Gizarte ekonomia & Bestelako elkartea \\
\hline 23,1 & 34,8 & 17,6 & 3,8 \\
\hline
\end{tabular}

Iturria: geuk sortua.

Aplikatutako EEE motari dagokionez, EEE motaren bat aplikatu duten Gipuzkoako erakundeen artean (\%24), etete EEEa gehiago aplikatu da (\%75) iraungitze EEEa baino (\%33,3). Datuen arabera, iraungitze EEEa sozietate anonimoetan eta gizarte ekonomiako sozietateetan erabili da gehien.

\section{7. taula}

Enplegua erregulatzeko espediente motak forma juridikoa kontutan hartuta (\%) G.11.1. Zein motakoa?

\begin{tabular}{l|cccc}
\hline \multirow{2}{*}{ Kategoria } & \multicolumn{4}{|c}{ Forma juridikoa } \\
\cline { 2 - 5 } & $\begin{array}{c}\text { Elkarte } \\
\text { mugatua }\end{array}$ & $\begin{array}{c}\text { Akziokako } \\
\text { elkartea }\end{array}$ & $\begin{array}{c}\text { Gizarte } \\
\text { ekonomia }\end{array}$ & $\begin{array}{c}\text { Bestelako } \\
\text { elkartea }\end{array}$ \\
\hline Etengarria & 52,4 & 91,3 & 100 & 100 \\
Murriztaila & 38,1 & 34,8 & 0 & 0 \\
\hline
\end{tabular}

Iturria: geuk sortua.

EEEek zenbaten gainean izan duten eragina aztertuta, ondorio hauek atera ditugu: EEE motaren bat aplikatu duten Gipuzkoako erakundeen artean (\%24), kasuen \%52,1 etan erakundeko langile guztiengan edo ia guztiengan izan du eragina. 
Eta bukatzeko, EEE motaren bat aplikatu duten Gipuzkoako erakundeen artean (\%24) ez dirudi genero aldagaiak garrantzirik duenik; izan ere, hamar kasutik zazpitan baino zerbait gehiagotan EEEak berdin ukitu ditu gizonezko zein emakumezko langileak.

\section{8. taula}

Enplegua erregulatzeko espedienteak generoaren arabera forma juridikoa kontutan hartuta (\%)

G.11.3 Zein perfiletan aplikatu da neurri hori?

\begin{tabular}{l|cccc}
\hline \multirow{2}{*}{\multicolumn{1}{c|}{ Kategoria }} & \multicolumn{4}{c}{ Forma juridikoa } \\
\cline { 2 - 5 } & $\begin{array}{c}\text { Elkarte } \\
\text { mugatua }\end{array}$ & $\begin{array}{c}\text { Akziokako } \\
\text { elkartea }\end{array}$ & $\begin{array}{c}\text { Gizarte } \\
\text { ekonomia }\end{array}$ & $\begin{array}{c}\text { Bestelako } \\
\text { elkartea }\end{array}$ \\
\hline Gizonezkoetan soilik & 23,8 & 17,4 & 0 & 0 \\
\hline Gehienbat gizonezkoetan & 9,5 & 4,3 & 33,3 & 0 \\
\hline $\begin{array}{l}\text { Gizonezkoetan eta emakumezkoe- } \\
\text { tan, berdin-berdin }\end{array}$ & 66,7 & 78,3 & 66,7 & 100 \\
\hline Gehienbat emakumezkoetan & 0 & 0 & 0 & 0 \\
\hline Emakumezkoetan soilik & 0 & 0 & 0 & 0 \\
\hline
\end{tabular}

Iturria: geuk sortua.

Bestalde, erakundearen arrazoiak direla eta, enpleguari eusteko beste bide bat ere identifikatu dugu gure ikerketan: pertsonak beste lantoki batzuetara mugitzea. Jarraian, neurri hori Gipuzkoako erakundeetan nola aplikatzen den ikusi ahal izango dugu, gure landa-laneko emaitzak aztertuta.

\subsection{Pertsonak beste lantoki batzuetara mugitzea}

Gure landa-laneko emaitzei erreparatzen badiegu, ikus dezakegu aztertutako kasuen \%16,5ean lantoki batetik bestera mugitu direla langileak. Neurri horrek garrantzi berezia izan du Gipuzkoako gizarte ekonomiako erakundeetan, 2008az geroztik gaur egun arte.

Mugigarritasun neurriek emakume eta gizon enplegatuen artean izan duten eraginari begiratuz gero, emaitzek erakusten dute bi generoen arteko banaketa orekatua dela Gipuzkoako erakundeetan, oro har. 


\section{9. taula}

Langileak lantokiz aldatzea forma juridikoa kontutan hartuta (\%)

G.10. Langileak beste lantoki batzuetara aldatzeko neurriak kudeatu dira? Bai

\begin{tabular}{cccc}
\hline \multicolumn{4}{c}{ Forma juridikoa } \\
\hline Elkarte mugatua & Akziokako elkartea & Gizarte ekonomia & Bestelako elkartea \\
\hline 13,2 & 15,2 & 47,1 & 11,5 \\
\hline
\end{tabular}

Iturria: geuk sortua.

\section{0. taula}

Langileak lantokiz aldatzea generoaren arabera forma juridikoa kontutan hartuta (\%)

G.10.1. Zein perfiletan aplikatu da neurri hori?

\begin{tabular}{l|cccc}
\hline \multirow{2}{*}{\multicolumn{1}{c}{ Kategoria }} & \multicolumn{4}{c}{ Forma juridikoa } \\
\cline { 2 - 5 } & $\begin{array}{c}\text { Elkarte } \\
\text { mugatua }\end{array}$ & $\begin{array}{c}\text { Akziokako } \\
\text { elkartea }\end{array}$ & $\begin{array}{c}\text { Gizarte } \\
\text { ekonomia }\end{array}$ & $\begin{array}{c}\text { Bestelako } \\
\text { elkartea }\end{array}$ \\
\hline Gizonezkoetan soilik & 16,7 & 30 & 0,0 & 0,0 \\
\hline Gehienbat gizonezkoetan & 8,3 & 40 & 12,5 & 0,0 \\
\hline $\begin{array}{l}\text { Gizonezkoetan eta emakumezkoe- } \\
\text { tan, berdin-berdin }\end{array}$ & 50,0 & 20 & 87,5 & 66,7 \\
\hline Gehienbat emakumezkoetan & 0,0 & 10 & 0,0 & 33,3 \\
\hline Emakumezkoetan soilik & 25,0 & 0 & 0,0 & 0,0 \\
\hline
\end{tabular}

Iturria: geuk sortua.

\section{Erretiroak}

Gure landa-lanean beste dimentsio bat ere aztertu dugu: erretiro aurreratuak, erakundeek, enplegua banatzeko orduan, neurri hori ere erabili baitute. Ildo horretatik, erretiro aurreratuari eta erretiro partzialari buruzko datuak aurkeztuko ditugu jarraian.

Euskal Autonomia Erkidegoan, aspaldidanik uste izan da erretiro partziala formula egokia dela lan jarduera osotik erretirora poliki-poliki igarotzeko eta, aldi berean, enplegu berria sortzeko. Gaur egun indarrean 
dagoen legeriak, ordea, kontratu mota hori erabiltzeko baldintzak gogortu ditu, Gizarte Segurantzarentzat dakarren kostua dela eta. Antzekoa gertatu da erretiro aurreratuarekin ere. Horregatik, erretiro adinera hurbiltzen ari diren pertsonentzat neurri horiek ez dira jada hain erakargarriak.

\subsection{ERRETiro PARTZIALAK ETA TXANDAKo LAN KONTRATUAK}

Erretiro partziala errelebo kontratuarekin uztartzen duen neurria oso erabilia izan da, datuak ditugun lehenengo urteetatik bertatik. Gure landa-lanean lortu ditugun emaitzei begiratuta, azterketa honetan parte hartu duten Gipuzkoako erakundeen \%37k diote krisi garaian erretiro partzialak egin dituztela, errelebo kontratuekin batera. Neurri hori erabili dute, nagusiki, sozietate anonimoek.

\section{1. taula}

Erretiro partzialak eta txandako lan kontratuak forma juridikoa kontutan hartuta $(\%)$

G.15. Krisialdi honetan erretiro partzialak eta txanda-kontratuak konbinatu dira? Bai

\begin{tabular}{cccc}
\hline \multicolumn{4}{c}{ Forma juridikoa } \\
\hline Elkarte mugatua & Akziokako elkartea & Gizarte ekonomia & Bestelako elkartea \\
\hline 24,2 & 57,6 & 35,3 & 30,8 \\
\hline
\end{tabular}

Iturria: geuk sortua.

Nabarmen agertzen da neurri mota horrek gizonei eragin diela nagusiki. Errelebo kontratuekin konbinatutako erretiro partzial guztien ia bi herenak gehienbat $(\% 13,5)$ edo soilik $(\% 50)$ gizonei egin zaizkie. Gizonen protagonismoa ulergarria da, neurri handi batean, gizonak nagusi direlako neurri hori gehien erabili duten erakundeetako langile taldeetan (industria sektoreko enpresak, handiak eta sozietate anonimoak). 


\section{7. grafikoa}

Erretiro partzialak eta txandako lan kontratuak generoaren arabera (\%)

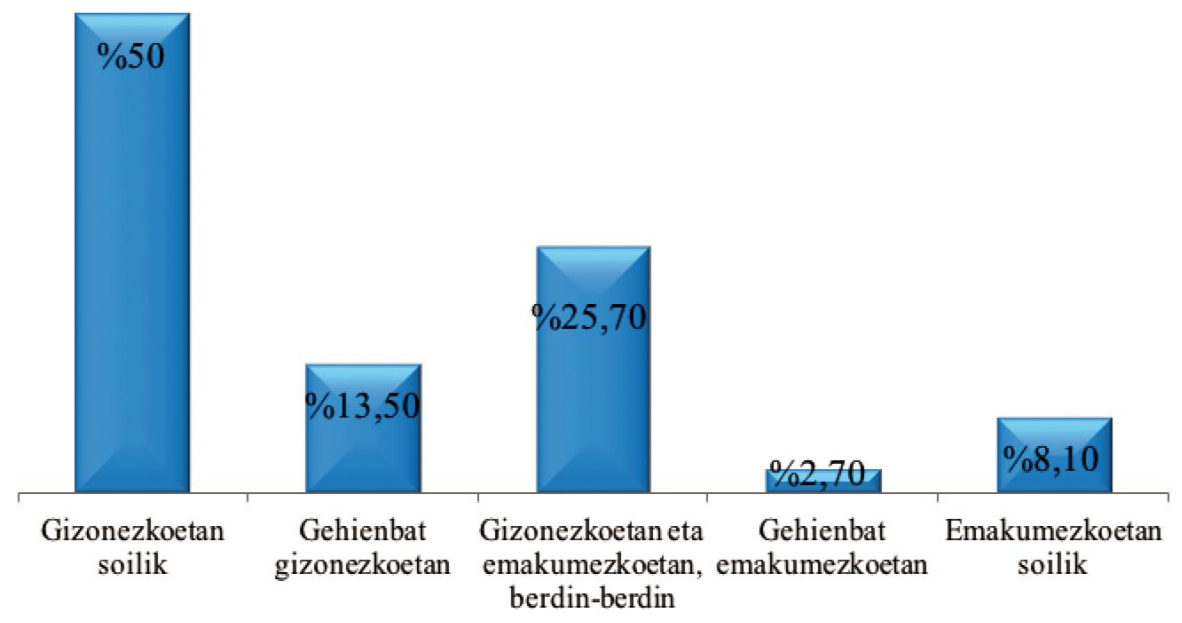

Iturria: geuk sortua.

\section{2. taula}

Erretiro partzialak eta txandako lan kontratuak, generoaren arabera forma juridikoa kontutan hartuta (\%)

G.15.1. Zein perfiletan aplikatu da neurri hori?

\begin{tabular}{lcccc}
\hline \multirow{2}{*}{ Kategoria } & \multicolumn{4}{c}{ Forma juridikoa } \\
\cline { 2 - 5 } & $\begin{array}{c}\text { Elkarte } \\
\text { mugatua }\end{array}$ & $\begin{array}{c}\text { Akziokako } \\
\text { elkartea }\end{array}$ & $\begin{array}{c}\text { Gizarte } \\
\text { ekonomia }\end{array}$ & $\begin{array}{c}\text { Bestelako } \\
\text { elkartea }\end{array}$ \\
\hline Gizonezkoetan soilik & 45,5 & 55,3 & 50,0 & 37,5 \\
\hline Gehienbat gizonezkoetan & 18,2 & 5,3 & 33,3 & 25,0 \\
\hline $\begin{array}{l}\text { Gizonezkoetan eta emakumezkoe- } \\
\text { tan, berdin-berdin }\end{array}$ & 27,3 & 31,6 & 0,0 & 12,5 \\
\hline Gehienbat emakumezkoetan & 0,0 & 2,6 & 16,7 & 0,0 \\
\hline Emakumezkoetan soilik & 9,1 & 5,3 & 0,0 & 25,0 \\
\hline
\end{tabular}

Iturria: geuk sortua. 


\subsection{ERretiro aURreratuak}

Gure landa-lanaren emaitzak aztertuz gero, Gipuzkoako lau erakundetatik batek egin du erretiro aurreraturen bat azken bost urte hauetan. Erretiro aurreratuko neurriak hartu dira, bereziki, gizarte ekonomiako erakundeetan.

\section{3. taula}

Erretiro aurreratuak forma juridikoa kontutan hartuta

G.16. Epealdi honetan erretiro aurreratuak eman dira? Bai

\begin{tabular}{cccc}
\hline \multicolumn{4}{c}{ Forma juridikoa } \\
\hline Elkarte mugatua & Akziokako elkartea & Gizarte ekonomia & Bestelako elkartea \\
\hline 20,9 & 27,3 & 58,8 & 11,5 \\
\hline
\end{tabular}

Iturria: geuk sortua.

Gipuzkoako erakundeetan egindako erretiro aurreratuetan (\%25), kasuen \%72an kontratazio berriak sortu dira. Taulako 16G galderari begiratzen badiogu, alegia, neurri horrek aparteko orduak areagotzea edo kontratazio berriak egitea ekarri duen, emaitzek erakusten dute kontratazio berrien ehunekoa handia dela Gipuzkoako erakunde mota orotan. Kontratu horietan gehienak partzialak dira.

\section{Emaitzen sintesia gizarte ekonomiaren ikuspuntutik}

Printzipioz, gizarte ekonomiako erakundeek Gipuzkoan emaitza hobeagoak lortu dute hainbat enplegu banaketarako neurritan:

- Kontratazio berrietan lagin osoak baino kontratazio berri gehiago egin dituzte eta gizonezkoak eta emakumezkoak berdintsu kontratatu dituzten enpresak dirudi.

- Aparteko lanorduei buruz, dirudi portaersa ezberdina dutela: Gizarte ekonomikoek jotzen dute gehien aparteko lanorduak konpentsatzera, eta sozietate anonimoek eta erantzukizun mugatukoek, aldiz, aparteko orduak ordaintzea hautatzen dute.

—Eszedentziek pisu handiagoa dute gizarte ekonomiako erakundee$\tan$.

- Prestakuntzarako baimenetan edo baimen partzialki ordainduetan, berriro ere, gizarte ekonomiako erakundeek gainerakoek baino baimen gehiago eman dituzte. 
- Argi dago bereziki gizarte ekonomiako erakundeetan erabili dela pertsonak beste lantoki batzuetara mugitzea lana mantentzeko neurri bezala.

— Gipuzkoako lau erakundetatik batean hartu dira erretiro aurreratuak eta erakunde horien artean nabarmentzekoak dira gizarte ekonomiakoak.

Baina beste arlo batzuetan gizarte ekonomiaren emaitzak ez dira hain honak:

- Kontratu motetan, gizarte ekonomiako erakundeek, oraingoan, laginaren batez bestekoak baino lanaldi osoko kontratazio berri gutxiago egin dituzte.

- Badirudi Gipuzkoako gizarte ekonomiako erakundeen artean, aparteko orduak ohikoagoak direla sozietate anonimoetan baino.

- Badirudi iraungitze EEEak arruntagoak izan direla Gipuzkoako gizarte ekonomiako erakundeetan eta sozietate anonimoetan ere.

Dena dela, krisiaren momentu latzenak pasa ondoren, gaur egun kontestu ekonomikoa aldatzen dagoela ikusita, interesgarria izango litzateke berriro aztertzea enpresek orain, hiru urte beranduago, nola aldatu dute beraien portaera enplegu banaketaren eta enplegu sortzearen ikuspuntutik.

\section{Bibliografia}

Aller Platas, M.I. (2013). «Mini-midi jobs, empleo a tiempo parcial, jornada reducida subvencionada, desempleo parcial... la expansión de figuras de borrosos contornos entre empleo y paro y la persistencia de un modelo diferenciado de división sexual del trabajo (y empleo) en Alemania» Actas del IV Congreso de la Red Española de Política Social (REPS). Las politicas sociales entre crisis y post-crisis celebrado el 6 y 7 de junio en la Universidad de Alcalá. Recuperado de http://www3.uah.es/congresoreps2013/Paneles/panel1/mi_aller@yahoo.es/ TC1 comunimaler.pdf

Alonso, L.E. \& Perez Ortiz, L. (1996). ¿Trabajo para todos? Un debate necesario. Madrid: Ediciones Encuentro.

Anisi, D. (1996). "El reparto del trabajo». Información Comercial Española, $79-86$ zk.

Aznar, G. (1994). Trabajar menos para trabajar todos. Madrid: Ed. Hoac.

Bengoetxea Alkorta, A. (2016). «Régimen jurídico básico de las materias directamente vinculadas a la reducción del tiempo de trabajo» Lan harremanak: Revista de Relaciones Laborales, $34 \mathrm{zk}, 106-145$ or.

Bilbao, A. (1996). Una fantasía de la negociación sindical: el reparto del tiempo de trabajo. Cuadernos de Relaciones Laborales, 9 zk. 
Bilbao Saralegui, J. (1996). «Reparto del tiempo de trabajo como medida de creación de empleo: El caso vasco» Ekonomiaz: Revista vasca de economía, $34 \mathrm{zk}$, 183-190 or.

Bosch, G. (2010). "Reducción de horas, no de plantilla», Principios, estudios de economia politica, $17 \mathrm{zk}, 29-51$ or.

Castrillon Serna, V.; Zendoia Sainz, J.M. \& Zubiri Rey, J.B. (2016). «Propuestas de reducción del tiempo de trabajo en Gipuzkoa" Lan harremanak: Revista de Relaciones Laborales, $34 \mathrm{zk}, 255-292$ or.

Castrillon Serna, V. (2017). ¿Es posible reducir la jornada laboral? IDEAS Working Paper Series from RePEc.

Consejo Económico y Social (CES) (2018) Informe sobre el futuro del trabajo, Pleno 30 de mayo. Recuperado de http://www.ces.es/ documents/10180/5461461/Inf0318.pdf

De la Fuente Lavin, M. \& Zubiri Rey, J.B. (2016). «Significado histórico y actualidad de las políticas de reducción del tiempo de trabajo" Lan harremanak: Revista de Relaciones Laborales, $34 \mathrm{zk}, 19-48$ or.

De la Fuente Lavin, M. \& Zubiri Rey, J.B. (2016). «Efectos sobre el empleo de la reducción del tiempo de trabajo: Aprendizajes de la experiencia francesa». Lan harremanak: Revista de Relaciones Laborales, $34 \mathrm{zk}, 79-105$ or.

De la Puerta, J. et al. (1998). El tiempo que vivimos y el reparto del trabajo. Barcelona: Paidós.

Ferrer Sais, A. (2018). "El tiempo de trabajo y el reparto del empleo». Temas para el debate, $280 \mathrm{zk}$ (marzo), (ejemplar dedicado a: El trabajo decente), 38-42 or.

Fina Sanglas, L. \& Pérez Infante, J.I. (1999). «Las políticas de reparto de trabajo». Cuadernos de Información Económica, $150 \mathrm{zk}, 31-44$ or.

Gonzalez-Ruiz, M. (2004). «El reparto del trabajo, una política impostergable» Filosofía, politica y economía en el Laberinto, 14 zk, 34-46 or.

Graaf, J. de (2010). «Reducir el horario laboral como vía hacia la sostenibilidad» en Worldwatch Institute, La situación del mundo 2010. Cambio Cultural. Del consumismo hacia la sostenibilidad, Barcelona: Icaria. Recuperado de https:// www.fuhem.es/media/cdv/file/biblioteca/Situacion_Mundo/2010/Reducirhorario-laboral_J_deGRAAF.pdf

Husson, M. (2016). «Reducción del tiempo de trabajo y desempleo: un escenario europeo" Lan harremanak: Revista de relaciones laborales, 34 zk., 293-301 or.

Jauregui, R.; Egea García, F. \& Puerta Gonzalez-Quevedo, J. de la (1998). El tiempo que vivimos y el reparto del trabajo: la gran transformación del trabajo, la jornada laboral y el tiempo libre. Barcelona: Ed. Paidós.

Keynes, J.M. (1930). «Las posibilidades económicas de nuestros nietos» en Keynes, J.M. (1931/1988). Ensayos de Persuasión, Barcelona. Editorial Crítica.

Lehndorf, S. \& Bosch, G. (1997). "La reducción de la jornada de trabajo y el empleo", Papeles de Economía Española, 72 zk, 342-345 or.

Ley General de la Seguridad Social: Texto refundido (1994). Boletín Oficial del Estado 154 zk de 29 de junio. 
Ley 35/2010, de 17 de diciembre de medidas urgentes para la reforma del mercado de trabajo (2010). Boletín Oficial del Estado de 18 de septiembre.

Medina Castillo, J.E. (1999). Crisis de la sociedad salarial y reparto del trabajo. Granada: Ed. Comares.

Morrissey, T., Fynes, B. \& Roche, W.K. (1996). «Análisis internacional sobre reparto de trabajo y creación de empleo». Revista Internacional del Trabajo, 115(2)zk, 139-170 or.

NEF (2010). 21 hours. Why a shorter working week can help us all to flourish in the 21st century. London: The New Economics Foundation. Itzulita: 21 horas Por qué una semana laboral más corta puede ayudarnos a todos a prosperar en el siglo XXI. Recuperado de http://www.slowpeople.org/docs/21horas_web.pdf

OIT (2011). El tiempo de trabajo en el siglo XXI. Informe para el debate de la Reunión tripartita de expertos sobre la ordenación del tiempo de trabajo (17-21 de octubre de 2011) Ginebra: Oficina Internacional del Trabajo. Recuperado de http://www.ilo.org/wcmsp5/groups/public/---ed_protect/--. protrav/---travail/documents/publication/wcms_162148.pdf

Proyecto 21 Proiektua (2017). Reparto de empleo: Reducción de jornada, organización del tiempo de trabajo y calidad de empleo. Pamplona: Observatorio de la Realidad Social (Departamento de Derechos Sociales del Gobierno de Navarra. Recuperado de http://www.navarra.es/NR/rdonlyres/E7FF7469-2FCE43BA-B908-25B0D5DFC6C1/399091/RepartodelEmpleo2.pdf

Rafols, R. (2010). «La reducción del tiempo de trabajo y una estrategia ecológica post-crecimiento». Ecología política. 8 diciembre. Recuperado de http://www. ecologiapolitica.info/? $\mathrm{p}=4553$

Real Decreto-Ley 3/2012, de 10 de febrero, de medidas urgentes para la reforma del mercado laboral (Ley 3/2012, de 6 de julio, de medidas urgentes para la reforma del mercado laboral) Boletín Oficial del Estado de 11 de febrero de 2012.

Real Decreto-Ley 16/2013, de 20 de diciembre, de medidas para favorecer la contratación estable y mejorar la empleabilidad de los trabajadores (2013) Boletín Oficial del Estado, $305 \mathrm{zk}$, de 21 de diciembre.

Recio, A. (2012). «Reparto del trabajo y modelo social». Papeles de relaciones ecosociales y cambio global. $118 \mathrm{zk}, 67-78$ or. Recuperado de https://core.ac.uk/ download/pdf/78524031.pdf

Rifkin, J. (1995). El fin del trabajo: Nuevas tecnologías contra puestos de trabajo: El nacimiento de una nueva era. Barcelona: Ed. Paidós.

Rodriguez Alvarez, A. (1996). «Del reparto del empleo al reparto del trabajo». El Futuro del trabajo. Reorganizar y repartir desde la perspectiva de las mujeres. Bilbao: Bakeaz.

Rosell, J. \& Trigo, J. (2000). El reparto del trabajo: el mito y la razón. Instituto de Estudios Económicos.

SIIS, Dokumentazio eta Ikerketa Zentroa / Centro de Documentación y Estudios (2015). Revisión sistemática de la efectividad de las medidas de reparto de empleo. Fundación Eguía-Careaga Fundazioa \& Gipuzkoako Foru Aldundia. 
SIIS, Dokumentazio eta Ikerketa Zentroa / Centro de Documentación y Estudios (2016). «Revisión sistemática de la efectividad de las medidas de reparto de empleo" Zerbitzuan: Gizarte zerbitzuetarako aldizkaria / Revista de servicios sociales, $61 \mathrm{zk}, 117-142$ or. 